\title{
Controlling Site to Evaluate History: Vegetation Patterns of a New England Sand Plain
}

\section{Citation}

Motzkin, Glenn, David Foster, Arthur Allen, Jonathan Harrod, and Richard Boone. 1996. Controlling Site to Evaluate History: Vegetation Patterns of a New England Sand Plain. Ecological Monographs 66, no. 3: 345-365. Portico. doi:10.2307/2963522.

\section{Published Version}

doi: $10.2307 / 2963522$

\section{Permanent link}

http://nrs.harvard.edu/urn-3:HUL.InstRepos:30673383

\section{Terms of Use}

This article was downloaded from Harvard University's DASH repository, and is made available under the terms and conditions applicable to Other Posted Material, as set forth at http:// nrs.harvard.edu/urn-3:HUL.InstRepos:dash.current.terms-of-use\#LAA

\section{Share Your Story}

The Harvard community has made this article openly available.

Please share how this access benefits you. Submit a story.

\section{Accessibility}




\title{
CONTROLLING SITE TO EVALUATE HISTORY: VEGETATION PATTERNS OF A NEW ENGLAND SAND PLAIN ${ }^{1}$
}

\author{
Glenn Motzkin, David Foster, Arthur Allen, Jonathan Harrod, ${ }^{2}$ And Richard Boone ${ }^{3}$ \\ Harvard Forest, Harvard University, Petersham, Massachusetts 01366 USA
}

\begin{abstract}
The widespread and long-lasting impact of human activity on natural ecosystems indicates that land-use history must be treated as an integral aspect of ecological study and a critical component of conservation planning. The New England landscape has undergone a complete transformation as forests were converted to agriculture in the 18th and 19th centuries followed by succession to woodland as a result of widespread agricultural abandonment. Despite the prevalence of human impacts, the effect and longevity of land-use practices on modern forest conditions are poorly understood. In the present study of pitch pine-scrub oak vegetation on a sand plain in the Connecticut Valley of Massachusetts, we address the following questions: (1) what is the relative importance of human and natural disturbance and environmental factors in controlling vegetation composition, structure, and landscape patterns; (2) what are the mechanisms underlying human impacts on vegetation, and what is the duration of these impacts; and (3) what are the implications of land-use history for the interpretation and conservation of these communities? Sand plain vegetation was selected for investigation because the homogeneity of site conditions facilitates the interpretation of land-use and natural disturbance impacts, and because the uncommon vegetation and constituent species are priorities for conservation efforts.
\end{abstract}

Paleoecological data suggest that pre-European fires were common on the study area, perhaps ignited by a large regional Indian population. The area was noted historically as an extensive pine plain and was used for wood products from the 18th to the mid-19th century. Eighty-two percent of the area was subsequently plowed for agriculture before being abandoned in the early 20 th century.

Soil analyses confirm the homogeneity of site conditions and suggest that land uses (plowing, woodlot/pasture) were determined according to ownership pattern rather than site factors. Previously cultivated parcels have distinct Ap (plow horizons) $15-33 \mathrm{~cm}$ deep, whereas uncultivated parcels have A horizons $3-10 \mathrm{~cm}$ in depth. Soil physical and chemical characteristics are similar among land uses and modern vegetation types.

Aerial photographs document a dramatic transformation in plant cover over the last 50 yr. In 1939, the vegetation was grassland or shrub-heath (49\%), open-canopy forest (29\%), and scrub-oak shrublands $(15 \%)$. In $1985,73 \%$ of the study area was forested with pitch pine $(40 \%)$, hardwood $(12 \%)$, or mixed stands $(21 \%), 9 \%$ was in open-canopy stands, and $3 \%$ was covered by grass or shrubs.

Vegetation/land-use relations are striking. Pitch pine occurs almost exclusively (97\%) on former plowed sites, whereas scrub oak stands occur preferentially (89\%) on sites that have not been plowed. Land use explains the greatest variation in modern vegetation as well as the distribution and abundance of many taxa. Fire has been common across the study area but has influenced vegetation largely within patterns resulting from prior land use. Land-use patterns and factors controlling vegetation composition and structure are broadly paralleled at similar sites elsewhere in the Connecticut Valley.

The study indicates that conservation biologists interested in preserving species, communities, and landscape patterns on sand plains in the northeastern United States need to incorporate a dynamic perspective of biological systems that includes the overriding impact of prior land use. In order to appreciate, study, and display these land-use and vegetation patterns it is essential to conserve the mosaic of assemblages and historical uses within a landscape setting.

Key words: conservation; disturbance; fire; land-use history; New England; pitch pine; sand plain; scrub oak; soil.

\footnotetext{
${ }^{1}$ Manuscript received 15 March 1995; revised 5 September 1995; accepted 26 September 1995; final version received 8 November 1995.

${ }^{2}$ Present address: Curriculum in Ecology, University of North Carolina, Chapel Hill, North Carolina 27599-3275 USA.

${ }^{3}$ Present address: Institute of Arctic Biology, University of Alaska, Fairbanks, Alaska 99775 USA.
} 


\section{INTRODUCTION}

Historical and modern human activities influence forest composition, structure, and function worldwide. European landscapes have been modified by humans since the Mesolithic; broad areas of Central and South America were transformed by prehistoric Indian societies; and all of eastern North America has been impacted since European settlement (Birks et al. 1988, Turner et al. 1990, Gomez-Pompa and Kaus 1992, Whitney 1994). Despite the geographical and temporal pervasiveness of human impacts on forest ecosystems, the specific effects of land-use history on vegetation development and ecosystem processes are poorly understood. In particular, little is known about the magnitude and duration of land-use impacts on modern species distributions, community structure and composition, and landscape pattern. An understanding of these relationships addresses fundamental ecological questions concerning the relative contribution of edaphic, biotic, and historical factors in controlling modern community organization and landscape structure (Egler 1954, Connell and Slatyer 1977, Huston and Smith 1987, Inouye et al. 1987). In addition, the documentation of vegetation dynamics within a land-

- scape context and the interpretation of underlying human and natural disturbance processes are critical for conservation planning (Ricklefs 1987, Hunter et al. 1988).

In this study, we investigate questions of basic ecological interest that address specific conservation concerns: (1) What are the contributions of human and natural disturbance vs. site factors in controlling plant species distributions, community structure and composition, and landscape patterns? (2) Are long-term land-use impacts primarily a consequence of the modification of edaphic conditions and environmental resources or of the physical removal of vegetation and subsequent biological constraints on dispersal, establishment, and growth? (3) What is the duration of landuse impacts on forested landscapes and how does this vary with respect to species composition, structure, and landscape pattern? (4) What implications does the integration of a historical understanding of vegetation dynamics and disturbance processes have on conservation of forested landscapes?

Previous investigations have correlated historical land-use patterns and modern species richness and distribution and have interpreted modern vegetation as reflecting variability in both physical conditions and land-use history (Wells et al. 1976, Peterken and Game 1981, Peterken and Game 1984, Whitney and Foster 1988, Duffy and Meier 1992, Brunet 1993, Hermy et al. 1993, Matlack 1994). However, attempts to determine the relative contribution of land-use vs. physical factors in controlling vegetation patterns are consistently confounded by the strong relationship between land use and initial site conditions (Glitzenstein et al. 1990, Foster 1992, Bratton and Miller 1994). In order to separate these factors, we chose to study pitch pinescrub oak communities on a broad sand plain, a landscape where historical land-use practices vary across a site that is unusually homogeneous with respect to topography, soil texture, and drainage. We anticipated that if analysis confirmed the homogeneity of soil conditions then it would be possible to detect land-use effects on vegetation structure, composition, and pattern. A second motivation for the study is that pitch pine-scrub oak communities are priorities for conservation throughout the Northeast because they are uncommon, support several rare plant and animal species, and have been substantially degraded by industrial, commercial, and residential development (Widoff 1987, Schweitzer and Rawinski 1988). Although considerable effort has been focused on the fire ecology of pitch pine-scrub oak communities (Little 1979), few studies have assessed historical land-use impacts on this regionally significant vegetation.

\section{Pitch pine-scrub oak in the northeastern United States}

Pitch pine-scrub oak (PPSO) communities occur across the northeastern United States on xeric, nutrientpoor sites, including excessively drained sand and gravel deposits and exposed ridgetops of acidic bedrock (Bromley 1935, Brierly 1938, Niering 1953, Seischab and Bernard 1991). PPSO communities are characterized by numerous species that have high concentrations of volatile secondary compounds, are highly flammable, and have strategies for survival or regeneration after fire (Specht 1979, Patterson et al. 1984). PPSO communities have experienced considerable human use, including harvesting of lumber, fuelwood, and naval stores, plowing for agricultural crops, livestock grazing, and conversion to industrial uses (Wacker 1979).

Considerable uncertainty exists with respect to the relationship between modern PPSO communities and the prior vegetation on these sites. Early investigators suggested that northeastern sand plains were dominated by grasslands or savanna-like vegetation before European settlement (Britton 1903, Harshberger 1916, Olmsted 1937). Schweitzer and Rawinski (1988) cite a highly specialized lepidopteran fauna (including rare species that are believed to have limited dispersal ability) to suggest that PPSO communities have existed for "millennia" at or near modern sites. In contrast, other studies suggest that the structure and composition of modern PPSO communities result from historical disturbances (especially fire) and varied site conditions (Whittaker 1979, Olsvig 1980, Milne 1985). Although a wide range of historical land uses are recognized for these sites (e.g., Wacker 1979), no prior research has 
evaluated human impacts on modern community patterns.

\section{STUdy Site}

Montague Plain in central Massachusetts $\left(42^{\circ} 34^{\prime} \mathrm{N}\right.$, $72^{\circ} 31^{\prime} \mathrm{W}$ ) is an outwash delta of primarily sand and gravel deposited into Glacial Lake Hitchcock, which occupied much of the Connecticut River Valley for several thousand years after Wisconsinan glaciation. Similar delta deposits are found throughout the Connecticut Valley, although most have been developed for industrial, commercial, or residential use. The surface of the $\sim 775$-ha study area is flat and ranges from 96 to $112 \mathrm{~m}$ above sea level. A series of ice-block depressions occurs on the eastern side of the sand plain along the Eastern Border Fault that separates the Connecticut Valley Lowland, a Mesozoic sedimentary basin, from the Central Uplands physiographic region (primarily Paleozoic gneiss and schist). Ponds occur in several depressions that intersect the groundwater table at $\sim 20 \mathrm{~m}$ below the surface of the delta. Geological studies as well as our own investigations suggest that the absence of restricting layers within the permeable sands and gravels renders the site highly prone to drought despite well-distributed annual precipitation of $\sim 110 \mathrm{~cm}$ (Mott and Fuller 1967; W. S. Motts, Harvard Forest Archives 1993-25, unpublished manuscript). Soils on the plain developed in water-sorted siliceous sand and gravel, with a surface layer of loamy sand resulting from eolian deposition following lake drainage.

\section{METHODS}

\section{Ownership, land use, and fire history}

Historical property maps drawn from original deeds were available for $1850,1900,1958$, and 1974 (W. Wentworth, Harvard Forest Archives 1993-25, unpublished maps). These maps were digitized (see Data analyses: Areal analyses) and combined into a composite parcel map of all known property boundaries. Boundaries from the original 1745 division of the plain were not included because considerable uncertainty exists as to their exact location.

Land-use history was determined in the field by examining soils for presence/absence and depth of a plowed surface (Ap) horizon and by noting artifacts of human activity (e.g., cut stumps, barbed wire, and plow mounds). Land-use boundaries were delineated on the composite parcel map by augering the soil along transects within each parcel.

We reviewed agricultural, cultural, and ecological sources, including histories and geological studies (e.g., Clapp 1895, Pressey 1910, Jahns 1966, Mott and Fuller 1967), unpublished data and maps from the Massachusetts Historical Commission and local historical societies, and background studies for industrial development of the area (e.g., Anonymous 1974, Thomas
1974; W. S. Motts, unpublished manuscript, W. Wentworth, unpublished manuscript). Interviews were also conducted with local historians (L. Girard and R. B. Livingston). Additional information on the timing of agricultural activity and abandonment was derived from aerial photographs (see Aerial photo analyses) and from the use of increment cores to determine the maximum age of trees in stands throughout the plain.

To reconstruct the recent fire history (1928-1994), we tabulated the size of all fires on and adjacent to the plain (Turners Falls Fire Department, unpublished data). For fires $\geq 2$ ha and in cases where areal estimates were missing, we reviewed local newspapers to confirm fire size and location. Information on earlier fires was derived from annual reports from the Town of Montague (1900-1928) and from newspapers and published histories.

\section{Aerial photo analyses}

Stand maps depicting major patterns of forest composition and structure were derived from 1985 aerial photographs (1:25000, color-infrared). Extensive field work enabled us to refine the interpreted classification and apply it to 1939 aerial photographs (1:36 000, black and white) with the addition of three nonforested types that did not occur in 1985. Stand delineations for 1939 and 1985 were georeferenced to U.S. Geological Survey topographic maps using a zoom transfer scope prior to digitizing (see Areal analyses).

\section{Modern vegetation and soils}

In order to evaluate the effects of land use on modern vegetation and soils, we stratified sampling by 1985 stand and composite parcel boundaries, with one plot sampled within each stand in a parcel (Fig. 1). Field checking ensured that soils and land use were homogeneous across each sampling unit. At each of 12120 $\times 20 \mathrm{~m}$ sample plots, we estimated percent cover of all herb, shrub, and sapling $(<2.54 \mathrm{~cm}$ diameter-atbreast-height $[\mathrm{dbh}])$ species in eight cover-abundance classes $(1=$ rare, $<1 \% ; 2=$ few,$<5 \% ; 3=$ numerous, $<5 \% ; 4=5-15 \% ; 5=16-25 \% ; 6=26-50 \% ; 7=$ $51-75 \% ; 8=>75 \%)$. Diameter at breast height was recorded for all trees $(>2.54 \mathrm{~cm} \mathrm{dbh})$. Evidence of disturbance, including windthrow mounds, cutting, fire scars, stem charring, and soil charcoal, was recorded at each plot.

Within each plot, two soil pits were dug and full profile descriptions prepared following standard Soil Conservation Service methods (USDA 1993). Pits were randomly located a minimum of $8 \mathrm{~m}$ apart and were dug into the $\mathrm{C}$ horizon (parent material) to an average depth of $80 \mathrm{~cm}$. Samples of the Oe and Oa horizons were taken under a $15 \times 15 \mathrm{~cm}$ template, and $0-15$ and $15-30 \mathrm{~cm}$ mineral soils were sampled with a $5 \times$ $15 \mathrm{~cm}$ cylindrical steel corer. These depth intervals were chosen to sample deep plow layers and to allow for comparisons between surface soils from plowed and 


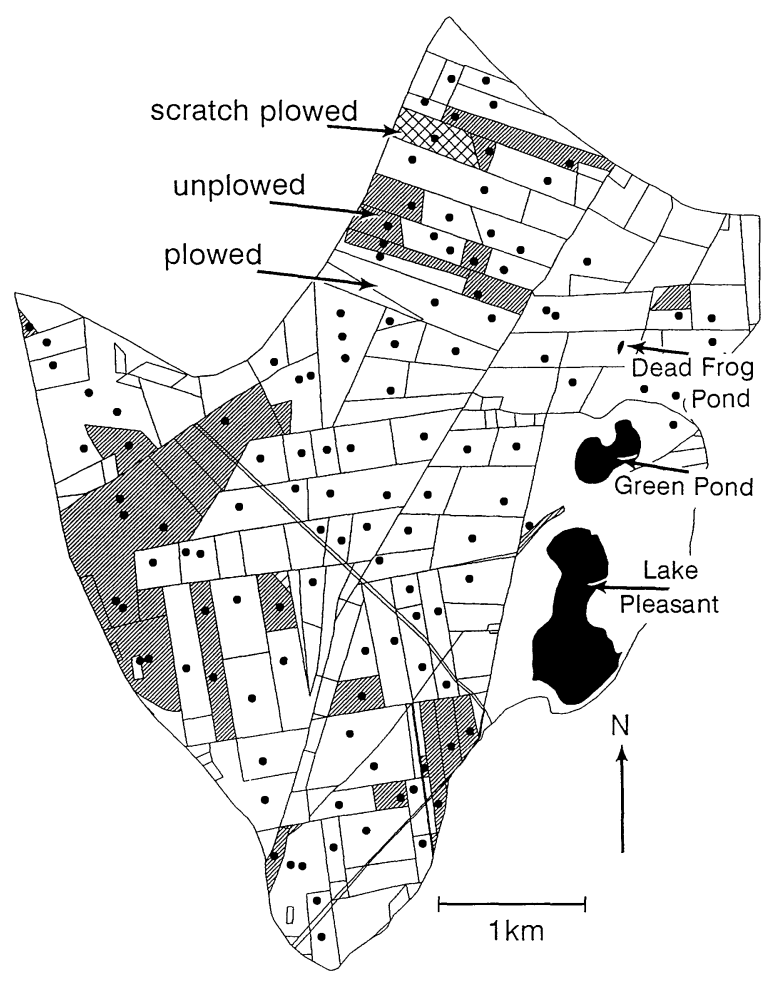

Fig. 1. The Montague Plain study area showing the lo- cation of sample plots within historical ownership and landuse boundaries determined by presence of Ap horizons: white $=$ formerly plowed; narrow diagonal shading = unplowed; cross-hatched shading $=$ minimally or scratch plowed. Stratification of sampling within stands delineated from 1985 aerial photos (not shown) accounts for parcels with more than one sample plot.

unplowed sites where A horizons vary greatly in depth. In the laboratory, samples were air-dried, sieved (2.0 $\mathrm{mm}$ for mineral soil, $5.6 \mathrm{~mm}$ for Oe and Oa layers), and weighed for bulk density. Subsamples were ovendried at $105^{\circ} \mathrm{C}$ to obtain gravimetric water content and combusted at $500^{\circ} \mathrm{C}$ to determine organic matter content. Soil $\mathrm{pH}$ was determined for air-dried samples (1: 2, mineral soil : water; 1:10, organic horizons : water). Concentrations of $\mathrm{NH}_{4} \mathrm{OAc}$-extracted exchangeable soil cations $(\mathrm{K}, \mathrm{Mg}$, and $\mathrm{Ca}$ ) were determined by atomic absorption/emission spectrophotometry (Thomas 1982) for samples from 33 plots (27\% of total) randomly distributed among the seven major vegetation types (see Vegetation characterization). Field moisture content of $0-15$ and $15-30 \mathrm{~cm}$ mineral soils was determined gravimetrically on adjacent plowed and unplowed sites ( 8 plowed, 8 unplowed).

\section{Data analyses}

Areal analyses.-The following data layers were digitized in a vector format using ROOTS (CorsonRickert 1992): topography (3 m [10 foot] contour intervals), 1985 vegetation, 1939 vegetation, composite parcel map, historical land use (presence or absence of
Ap), and 1993 sample-plot locations. Area and crosstabulation analyses were performed in the IDRISI Geographic Information System (Eastman 1992) with a pixel resolution of $10 \times 10 \mathrm{~m}$.

Vegetation characterization.-Species abundance data were ordinated using Detrended Correspondence Analysis (DCA; Hill 1979a) and nonmetric multi-dimensional scaling (McCune 1993), and a vegetation classification was developed using two-way indicator species analysis (TWINSPAN; Hill 1979b). Default settings were used for both DCA and TWINSPAN analyses except that TWINSPAN pseudospecies cut levels were matched to the cover abundance classes in order to avoid grouping values $>20 \%$ (Hill 1979b). Overstory data (trees $>2.54 \mathrm{~cm} \mathrm{dbh}$ ) were combined with understory data (herbs, shrubs, and trees $<2.54 \mathrm{~cm}$ $\mathrm{dbh}$ ) as follows: the maximum live basal area for a single species on a plot (pitch pine $=45.9 \mathrm{~m}^{2} / \mathrm{ha}$ ) was assigned a value of $100 \%$. Basal area classes corresponding to the eight cover-abundance classes used for the understory were then calculated as a percentage of this maximum. Overstory and understory individuals of the same species were treated as separate species.

Relationship of vegetation, environmental, and historical parameters.-Multiple regression of environmental variables vs. DCA ordination axis scores was used to evaluate the relationship of land-use, fire, and soil factors to vegetation variation. Several tests were used to determine environmental variability among vegetation types (defined by TWINSPAN analyses) and land uses. Due to nonparametric distribution of the soils data with respect to vegetation type, we performed Kruskal-Wallis tests on the untransformed data. Medians and confidence intervals $(95 \%)$ were calculated to determine whether soils differ by vegetation type. When grouped by land use, soil properties were normally distributed and $t$ tests were used to test for landuse differences. Tests of association $(G)$ were performed to test for differences between the frequency of occurrence of individual species on plowed vs. unplowed sites. Because of the large number of species tested, we subjected the results of the $G$ tests to the Sequential Bonferroni Test for multiple comparisons (Rice 1989).

\section{RESUlts}

\section{Ownership history}

The earliest reference to the study area occurs on a 1714 map of Swampfield (later Sunderland) where it appears as part of a large "barren pine plain, called Millers Plain" (Pressey 1910). In 1745, a general land division established $80,1-10$ ha lots in the southern portion of the plain (Clapp 1895, Pressey 1910); the remainder was divided following the establishment of the District of Montague in 1754. Many 18th century deeds list nonresidents as property owners, an indication of land speculation (Foster 1992; W. Wentworth, 
unpublished manuscript). Throughout the 19th century, ownership was concentrated among families that lived in the surrounding area and parcel sizes remained small (generally $<15 \mathrm{ha}$ ) suggesting that the land was actively being used. Consolidation of land by a few individuals occurred early in the 20th century, followed by corporate ownership and attempts at industrial development in recent decades.

\section{Land-use history}

Evidence of prehistoric human use of Montague Plain is limited, despite a long history of Indian occupation throughout the Connecticut Valley. A single Middle Woodland-period (AD 600-700) huntinggathering camp occurs adjacent to the plain (Thomas 1975), and Indian trails are reported to have crossed the site (Pressey 1910, Anonymous 1982).

Analysis of pre-European lake sediments provides suggestive evidence for aboriginal activity. Sites on the Montague Plain have high charcoal-to-pollen ratios in the 500-2000 yr prior to European arrival. These values are similar to coastal areas where Indian population densities were high and in contrast to upland areas where low Indian densities correspond to low amounts of sedimentary charcoal (Table 1). Because lightningignited fires are uncommon in New England (Patterson et al. 1984) and Indian population densities in the Connecticut Valley were quite high, it seems reasonable that high charcoal-to-pollen ratios reflect, at least in part, human-set fires (Patterson and Sassaman 1988). Historical accounts from the Connecticut Valley and coastal New England suggest that aboriginal peoples regularly used fire to improve hunting grounds, to drive

TABLE 1. Average pre-European charcoal abundance in several Massachusetts lakes. Charcoal-to-pollen ratios calculated according to methods of Clark (1982). Green Pond, Lake Pleasant, and Dead Frog Pond are at the eastern edge of the Montague Plain (see Fig. 1). Averages are based on values from $\sim 500-2000 \mathrm{yr}$ prior to European settlement for all ponds except Duck Pond, which includes data from $\sim 4500$ yr before European arrival.

\begin{tabular}{lllr}
\hline \hline \multicolumn{1}{c}{ Site } & \multicolumn{1}{c}{ Town } & \multicolumn{1}{c}{ Region } & $\begin{array}{c}\text { Char- } \\
\text { coal-to- } \\
\text { pollen } \\
\text { ratio }\end{array}$ \\
\hline Green Pond $\dagger$ & Montague & CT Valley & 515.8 \\
Lake Pleasant $\dagger$ & Montague & CT Valley & 295.8 \\
Dead Frog Pond $\dagger$ & Montague & CT Valley & 204.3 \\
Snake Pond $\dagger$ & Templeton & Upland & 33.5 \\
Silver Lake $\dagger$ & Athol & Upland & 88.6 \\
Aino Pond $\dagger$ & Ashburnham & Upland & 42.5 \\
Lily Pond $\dagger$ & Warwick & Upland & 78.3 \\
Little Mirror $\dagger$ & Harvard & Upland & 55.2 \\
Larkum Pond $\ddagger$ & Otis & Upland & 27.5 \\
Duck Pond $\ddagger$ & S. Wellfleet & Coastal & 250.7 \\
Charge Pond $\ddagger$ & Wareham & Coastal & 713.9 \\
Widgeon Pond $\ddagger$ & Wareham & Coastal & 580.7 \\
\hline
\end{tabular}

$\dagger$ D. R. Foster (unpublished data).

$\ddagger$ Data from Patterson and Sassaman (1988).

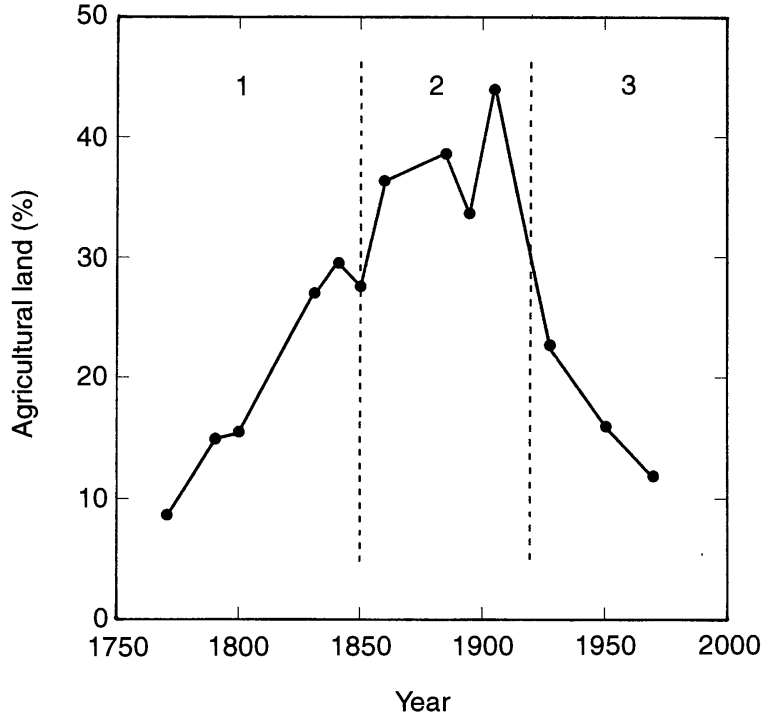

FIG. 2. Historical changes in the amount of agricultural land in the Town of Montague (7933 ha), including tillage, mowing, and pasture. Numbers correspond to general periods of land use on Montague Plain: 1 = pre-agricultural period characterized by timber and forest product extraction; $2=$ agricultural period when $\approx 80 \%$ of the plain was cultivated; 3 = agricultural abandonment and reforestation.

game, and to prepare land for agriculture (Judd 1905, Day 1953, Patterson and Sassaman 1988).

Indian populations were decimated and European populations increased through the 17 th and 18 th centuries. Although Montague Plain was divided into small parcels in the mid-18th century, anecdotal accounts and deed references to "lumber roads" crossing the plain indicate that harvesting of forest products may have been the primary land use through the early 19 th century (Fig. 2-period 1; Clapp 1895; W. Wentworth, Harvard Forest Archives 1993-25, unpublished manuscript). Dwight (1821) noted extensive "yellow pine plains" in Montague, and an 1830 map depicts the plain forested with pines (Massachusetts Archives 1830). Agricultural activity between the mid-19th and early 20th century probably accounts for most of the plowing that occurred on the plain (Fig. 1). This period corresponds to the period of maximum tillage in the Town of Montague (Fig. 2-period 2). Widespread abandonment of agriculture on the plain occurred by the early 20th century, with localized cultivation persisting until 1960 (Fig. 2-period 3). Land-use maps (WPA 1937) and 1939 aerial photographs indicate extensive "brushland", with only 3-9\% in agricultural use, primarily in the central, northern, and eastern areas. Old forest stands (up to $120 \mathrm{yr}$ ) occur on formerly plowed areas in the southern plain, which was evidently the first area abandoned (Thomas 1974). With the shift toward large corporate ownership in recent decades, unregulated recreation, illegal dumping, and vandalism have increased dramatically.

Anecdotal evidence suggests that corn and hay may 
TABLE 2. Fires $\geq 2$ ha on Montague Plain: January 1928May 1994. Dates and acreage estimates from the logbook of the Turners Falls Fire Department were checked in the Greenfield Recorder newspaper. Additional large fires that may have burned portions of the study area occurred on: 25 April 1932 (> 120 ha), 27 April 1938 (24 ha, Wills Hill), and 20 April 1976 (120 ha between Montague and Orange).

\begin{tabular}{|c|c|c|}
\hline Date & $\begin{array}{l}\text { Size } \\
\text { (ha) }\end{array}$ & Comments \\
\hline 9 October 1935 & $?$ & "large tract near Green Pond" \\
\hline 27 April 1937 & 485 & \\
\hline 7 May 1944 & $>400$ & $\begin{array}{l}\text { "worst blaze since 1938" (e.g., } \\
\text { 1937) }\end{array}$ \\
\hline 25 March 1945 & ? & Green Pond section \\
\hline 7 April 1945 & $<80$ & Lake Pleasant \\
\hline 15 April 1947 & 40 & north of Green Pond \\
\hline 10 May 1947 & ? & "large territory" near Wills Hill \\
\hline 5 March 1954 & $>40$ & “"well over 100 acres" \\
\hline 9 May 1957 & 190 & \\
\hline 15 August 1957 & 2 & $\begin{array}{l}\text { scrub oak and brush; near gravel } \\
\text { bank }\end{array}$ \\
\hline 16 April 1958 & 40 & four fires \\
\hline 28 October 1964 & 3 & east of gravel bank; near 1957 fire \\
\hline 9 July 1968 & 2 & woods road off Green Pond \\
\hline 3 April 1974 & 2 & $\begin{array}{l}\text { County Road and Hannegan } \\
\text { Brook }\end{array}$ \\
\hline 4 May 1980 & 2 & \\
\hline 24 June 1984 & 2 & $\begin{array}{l}\text { west of high tension wires, east of } \\
\text { TF Rd }\end{array}$ \\
\hline 18 August 1984 & $\begin{array}{r}3-4 \\
>70\end{array}$ & \\
\hline 3 May 1986 & $>70$ & south side of Wills Hill \\
\hline 26 July 1993 & 5 & burned to mineral soil locally \\
\hline
\end{tabular}

have been the primary agricultural products on Montague Plain. Corn fields are documented in the 1880s and in the early to mid-20th century by local residents that farmed or regularly visited the plain (Pressey 1910, Thomas 1974; L. Girard and R. B. Livingston, personal communication), and 1937 land-use maps (WPA 1937) indicate small hay fields. We found little barbed wire or other evidence to suggest that pasturing was widespread. Historical information suggests that permanent residences have never been built in the interior of the study area.

\section{Fire history}

Historical records are inadequate to reconstruct fire history prior to 1900 . Incomplete data from 1900-1928 document extensive fires in 1907 and 1911 and several smaller ones. Excellent records from 1928 onward identify 19 fires $\geq 2$ ha in size and indicate a major temporal shift in fire activity (Table 2). Eight fires exceeded 40 ha ( $\sim 5 \%$ of the study area), with seven between 1928 and 1958 and one in 1986. However, the number of fires $<2$ ha increased dramatically in recent decades, with at least 61 small fires since 1970. A similar pattern of large fires early in this century followed by many small fires in recent decades has been noted elsewhere in the northeastern United States (Fahey and Reiners 1981, Forman and Boerner 1981; W. A. Patterson III, personal communication) and is interpreted as resulting from improved fire detection and suppres- sion capabilities and an increase in accidental fires. Fires have occurred in every month of the year except January and February, but fire is most frequent in April and May prior to leaf-out of deciduous species.

\section{Broad vegetation patterns: 1939 and 1985}

Analyses of 1939 and 1985 stand maps document a major transformation in dominant vegetation over 46 yr (Fig. 3). In 1939, 49\% of the study area supported grassland or shrub-heath vegetation, $29 \%$ was open canopy stands $(25-50 \%$ forest cover), and $\sim 15 \%$ was occupied by scrub oak shrublands. Less than $1 \%$ of the plain supported closed canopy forests. Land-use maps from 1937 (WPA 1937) also depict little mature forest. Extensive field work identified few areas with tip-up mounds thereby ruling out widespread damage from the 1938 hurricane as the cause for the sparse forest cover. In $1985,73 \%$ of the study area was forested with either pitch pine $(40 \%)$, hardwood $(12 \%)$, or mixed stands (21\%); $9 \%$ supported open canopy $(25-50 \%$ cover) stands and only $3 \%$ was in grassland or nonscrub oak, shrubby vegetation. Scrub oak stands öccupied

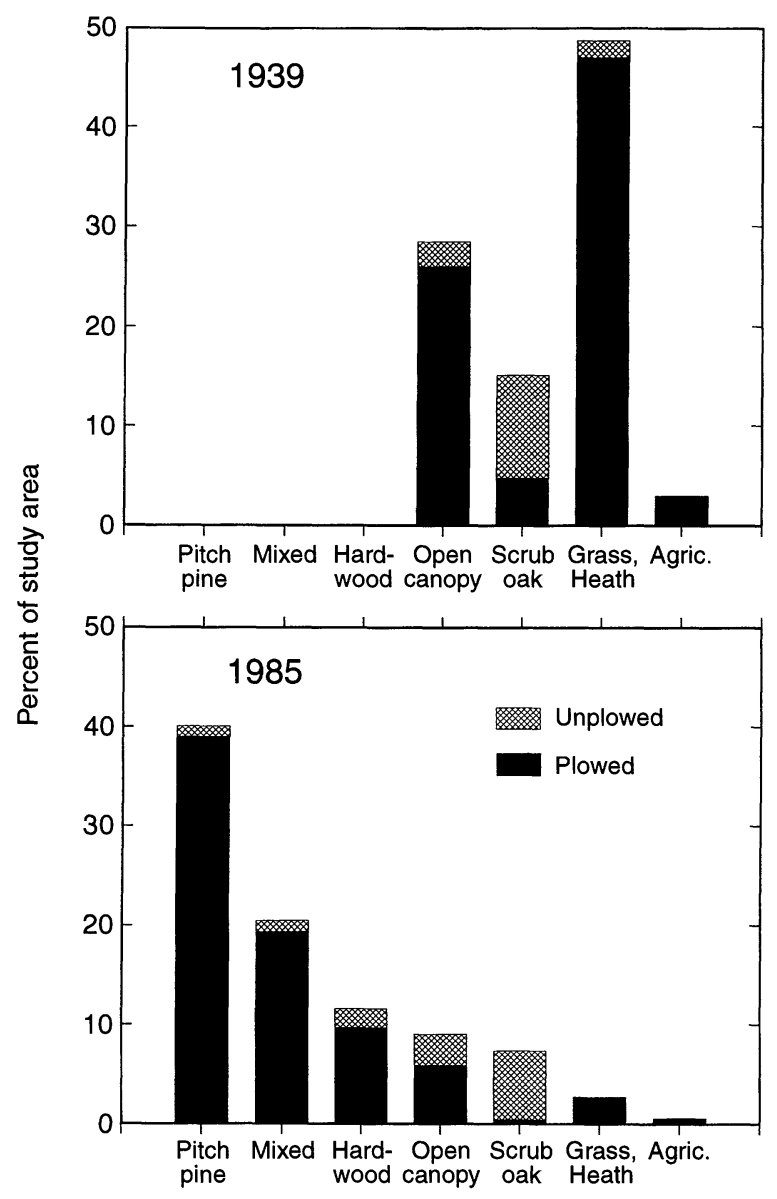

FIG. 3. The relationship between cover types and land use on Montague Plain in 1939 and 1985. Ponds (26.29 ha) were excluded from this analysis. 
$\sim 7.8 \%$ of the area in 1985 , approximately one-half of their acreage in 1939 (Fig. 3).

Of the $\sim 300$ ha of pitch pine woodlands present in 1985 , 97\% occurred on sites that were formerly plowed, whereas $89 \%$ of scrub oak stands occurred on sites that were never plowed (Figs. 3-4). Hardwood stands occupy $12-13 \%$ of both plowed and unplowed sites, whereas mixed forested stands occupy $\sim 23 \%$ of plowed areas but only $\sim 7 \%$ of unplowed sites. Modern forested stands (including pitch pine, hardwood, and mixed stands) occur primarily on areas that in 1939 supported mixed grass and shrub/heath vegetation or open-canopy stands ( $<50 \%$ cover) (Fig. 3 ). Whereas $84 \%$ of sites supporting scrub oak stands in 1985 also supported scrub oak in 1939, 53\% of 1939 scrub oak stands now support at least $25 \%$ forest cover.

\section{Vegetation composition}

Nonmetric multidimensional scaling and DCA ordinations were very similar; the following is based on DCA. Ordination of the vegetation data indicates considerable variability among plots (Fig. 5). Plots with low values for Axis 1 are dominated by scrub oak or mixed forest, whereas those characterized by pitch pine, grey birch, aspen, or grasslands have high values. Axis 2 distinguishes nonforested (e.g., scrub oak and grassland types) from forested vegetation (e.g., aspen, pitch pine, grey birch, and mixed stands).

Seven vegetation types that are distinct in species composition and abundance were identified using TWINSPAN and DCA (Table 3). Type 1 is characterized by high frequency and cover of graminoids (especially Andropogon scoparius) and forbs, including numerous weedy or early successional species. Shrubs characteristic of old fields such as Spiraea latifolia and Juniperus communis are frequent, whereas Vaccinium vacillans is less frequent than in all other types. Tree cover varies from no overstory to open Populus canopies above a well-developed herbaceous layer. Type 2 includes open Pinus rigida and Betula populifolia stands with frequent and abundant Polytrichum spp., Comptonia peregrina, Prunus pensylvanica, Andropogon scoparius, Vaccinium spp., Apocynum androsaemifolium, and Rubus spp. Pinus rigida forms the canopy in Type 3 and has an average abundance twice that in any other type. The understory includes Quercus spp., Acer rubrum, and Pinus strobus regeneration above abundant Polytrichum. Type 4 includes mixed Pinus strobus $-P$. rigida-hardwood stands, with few herbs, notably Monotropa uniflora, Lycopodium complanatum/tristachyum, and Pteridium aquilinum. Hardwoods dominate Type 5, with an overstory of Quercus coccinea above an ericaceous shrub layer of Gaylussacia baccata, Kalmia angustifolia, Gaultheria procumbens, and Vaccinium species. Type 6 includes dense stands of tall (1-3 m) scrub oak (Quercus ilicifolia) with varying tree cover. The understory of low shrubs and herbs includes Gaylussacia baccata (less
A

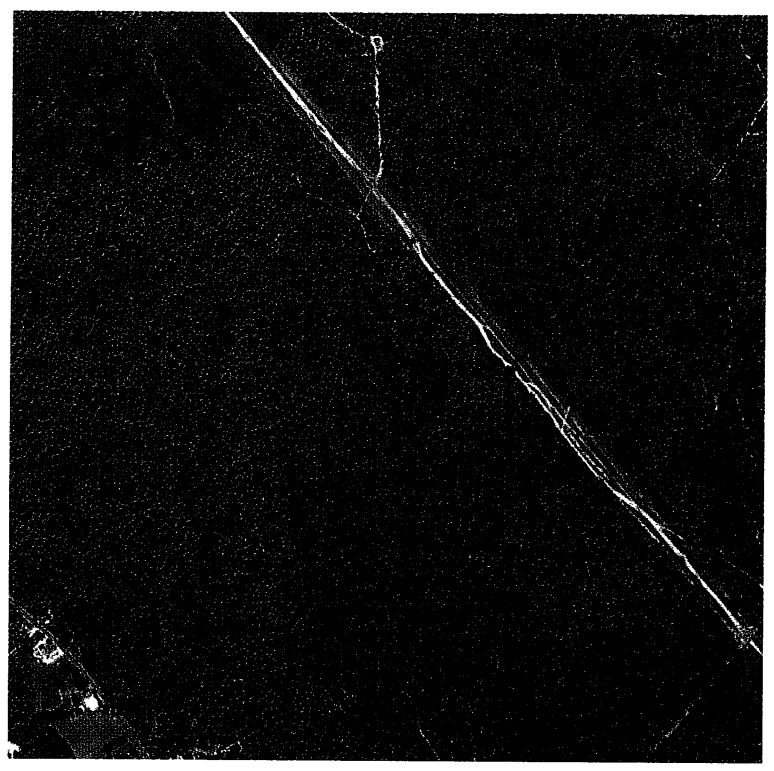

B

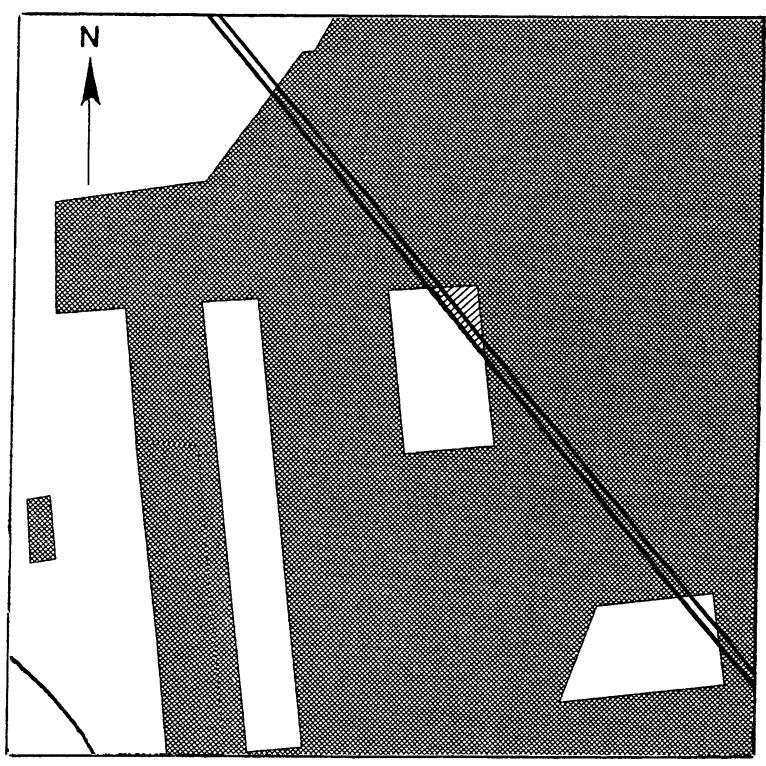

FIG. 4. 1985 color-infrared aerial photograph (A) and land-use map (B) of a portion of Montague Plain (scale: 1: $16000)$. Note several linear stand boundaries on the aerial photograph that correspond to land-use boundaries. Top: dark purple $=$ pitch pine; pink/red $=$ hardwoods; upper left corner $=$ extensive scrub oak stand. Bottom: white = unplowed; shading $=$ plowed; diagonal $=$ scratch plowed.

abundant than in Type 5), Vaccinium angustifolium, Pteridium aquilinum, and others. Type 7 is dominated by the shrubs Vaccinium angustifolium, Quercus prinoides, Viburnum cassinoides, Comptonia peregrina, and Quercus ilicifolia and has few trees. The herb layer includes species that are uncommon in other types such 

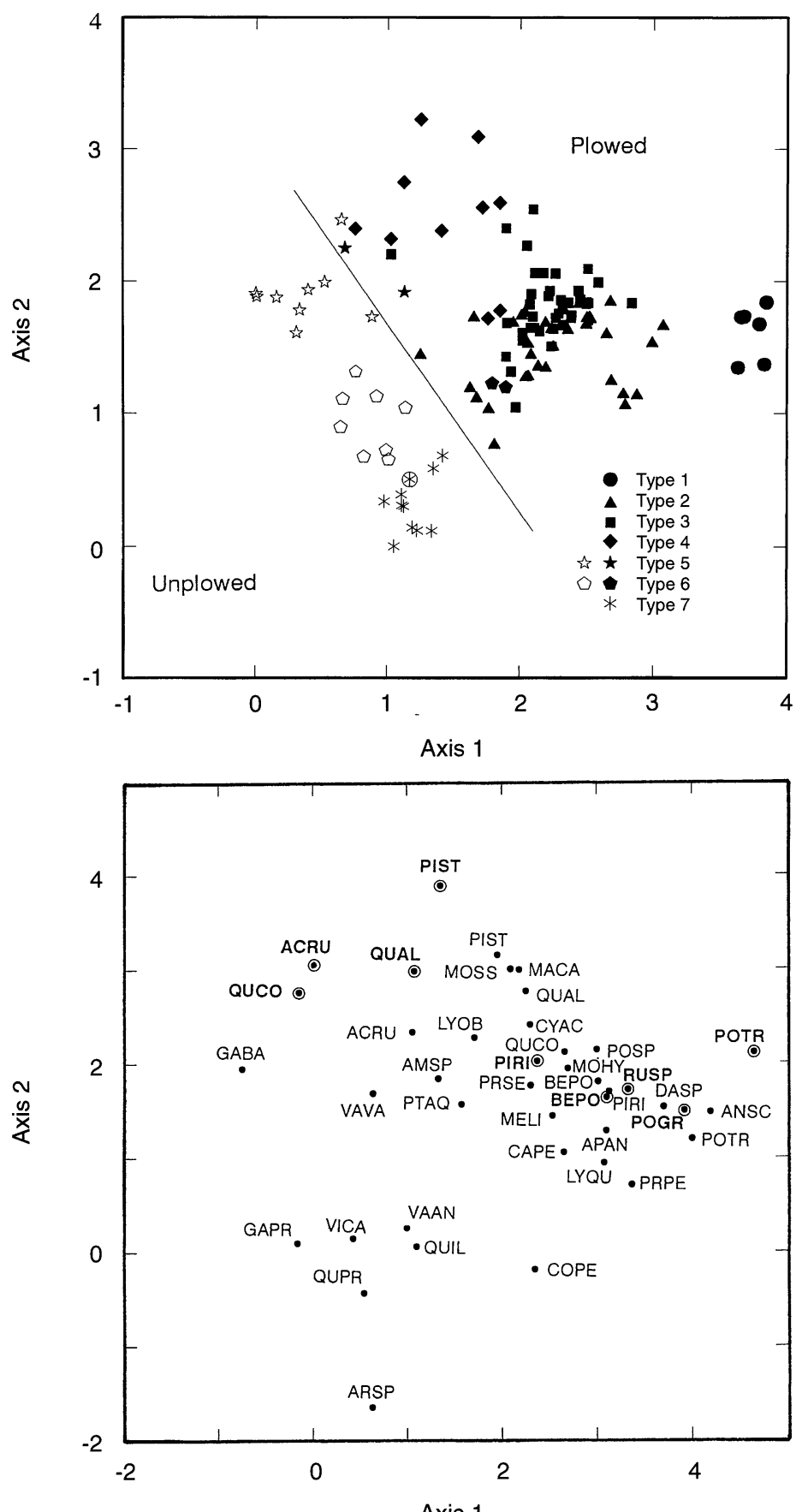

Axis 1

FIG. 5. Detrended correspondence analysis ordinations of 121 vegetation sample plots (top) and characteristic species (bottom) on Montague Plain. Note distinction between vegetation on plowed (closed symbols) vs. unplowed (open symbols) sites. The circled symbol in the lower left is a single plot on shallow scratch plowed soils. Symbols (top) refer to vegetation types described in the text. Overstory trees are indicated in bold (bottom). Species abbreviations are the first two letters each of the genus and species: Acer rubrum, Amelanchier spp., Andropogon scoparius, Apocynum androsaemifolium, Aronia sp., Betula populifolia, Carex pensylvanica, Comptonia peregrina, Cypripedium acaule, Danthonia spicata, Gaultheria procumbens, Gaylussacia baccata, Lycopodium obscurum, Lysimachia quadrifolia, Maianthemum canadense, Melampyrum lineare, Monotropa hypopithys, Pinus rigida, Pinus strobus, Polytrichum spp., Populus grandidentata, Populus tremuloides, Prunus pensylvanica, Prunus serotina, Pteridium aquilinum, Quercus alba, Quercus coccinea, Quercus ilicifolia, Quercus prinoides, Rubus spp., Vaccinium angustifolium, Vaccinium vacillans, and Viburnum cassinoides. 
as Lilium philadelphicum, Oryzopsis pungens, and Comandra umbellata.

Species richness ranges from 13 to 66 species per 400- $\mathrm{m}^{2}$ plot, with most plots supporting $15-30$ species (Table 3). Mean species richness is similar among vegetation Types 2-7 (21-28 species), whereas Type 1 supports an average of 45 species. Aerial photographs indicate that Type 1 occurs on those few sites that remained in agricultural use $30-50 \mathrm{yr}$ ago.

\section{Physical and chemical soil properties}

Field analysis of 242 soil profiles confirmed the homogeneity of texture, drainage, and soil classification and the heterogeneity of land-use soil disturbance across the site. All soils sampled are within the range of texture, bulk density, $\mathrm{pH}$, and cation concentrations reported for Windsor and Hinckley soil series in Massachusetts (Veneman 1985), and are similar to other excessively drained, sandy, siliceous soils (Forman 1979, Miller et al. 1979, Bockheim et al. 1983, Tilman 1987). Organic matter and cation concentrations are consistently lower than those found in finer textured, more fertile soils (Brady 1990, Troeh and Thompson 1993).

The presence of Ap (plow) horizons indicates that $82 \%$ of the Montague Plain was plowed (Fig. 1). Previously cultivated parcels have Ap horizons ranging from 15.5 to $33.0 \mathrm{~cm}$ in depth $(\bar{X}=21.5 \mathrm{~cm})$ that are light in color (Munsell color: 10YR 3/3-3/6) with smooth and abrupt boundaries (Figs. 6-7). Uncultivated parcels have A horizons ranging from 3 to 10 $\mathrm{cm}$ in depth $(\bar{X}=6.6 \mathrm{~cm})$ that are black (Munsell color: 10YR 2/1-2/2) and have more gradual boundaries. Two small areas $(<1 \%$ of the plain) have shallow $(12 \mathrm{~cm})$ Ap horizons that we interpret as "scratch plowed" or plowed minimally (Fig. 1). Cultivated Ap horizons have weak, fine granular structure, whereas uncultivated soils are massive and structureless in the upper horizons (A and B1). Surface soil gravel ( $>15 \%$ volume) occurs in $9 \%$ of pits in unplowed parcels and in $1 \%$ of pits in plowed parcels.

When $0-15 \mathrm{~cm}$ mineral soil properties (organic matter percent, bulk density, $\mathrm{pH}$, coarse fragment percent, and exchangeable cation concentrations) are compared by land use, significant differences are noted only for exchangeable potassium, organic matter, and bulk density (Table 4). Bulk density is greater in plowed sites $(P<0.000)$ and potassium and organic matter levels are higher in unplowed sites $(P=0.025$ and $P=0.003$, respectively). At $15-30 \mathrm{~cm}$, significant land-use differences are noted for organic matter $(P=0.003)$ and bulk density $(P=0.016)$, both of which are higher in plowed sites. Total organic matter by mass $(0-30 \mathrm{~cm})$ is slightly but significantly greater in plowed sites $(P$ $=0.045$ ). In 16 sites sampled for soil moisture content at field capacity, percent moisture by volume does not differ by land use at $0-15$ or $15-30 \mathrm{~cm}$ depths $(P=$ 0.5 ). Percent moisture by volume (mean $\pm 1 \mathrm{SE}$ ) for
$0-15 \mathrm{~cm}$ is $12.0 \%$ (range: $8.34-16.7$ ) on cultivated sites and $12.8 \%$ (range: $8.68-17.4$ ) on uncultivated sites.

Analysis of soil properties by vegetation type (defined by TWINSPAN) suggests considerable similarity among types (Table 5). Percent coarse fragments in $0-$ $15 \mathrm{~cm}$ mineral soils does not differ among types. Calcium and magnesium concentrations and $\mathrm{pH}$ are similar in all types with the exception of Type 1, which has significantly higher values. Potassium levels are higher in Types 6 and 7 than in Types 3 and 5, with intermediate values for the other types. Organic matter concentrations are higher and bulk densities lower in Types 5-7 than in 1-4. At $15-30 \mathrm{~cm}$, bulk densities do not differ and organic matter concentrations are generally similar among types, with a trend towards higher organic matter in Types 1-4 than in 5-7 (the reverse of what was noted for $0-15 \mathrm{~cm}$ depth). The $\mathrm{pH}$ at $15-30$ $\mathrm{cm}$ does not differ among types with the exception of high values for Type 1 . The total mass and concentration of organic matter for $0-30 \mathrm{~cm}$ mineral soils do not differ among cover types.

\section{Relationship of vegetation to environment}

Multiple regression enabled us to identify environmental variables that contribute to variability along DCA ordination axes (Table 6). Presence/absence of an Ap horizon is a significant explanatory variable along Axis $1(P<0.001)$; plots that were plowed have deep A horizons $(>15 \mathrm{~cm})$, high Axis 1 values, and are generally in vegetation Types 1-4. Plots in Types 5-7 have generally low Axis 1 values and, with few exceptions, unplowed A horizons (Fig. 5). Depth of the $\mathrm{O}$ horizon is identified as a second explanatory variable, with the deepest organic layers in pitch pine stands (Type 3 ) that have moderate to low Axis 1 values, and the most shallow ones in open grasslands and aspen stands (Type 1) with high values. Hydrogen ion concentrations are highest in plots with high Axis 1 values and relatively uniform elsewhere $(P=0.051)$. Significant explanatory variables for DCA Axis 2 are fire $(P<0.001)$, which occurs less frequently with increasing Axis 2 values, and depth of $\mathrm{O}$ horizon $(P$ $<0.001$ ), which increases along Axis 2. Presence/absence of Ap horizons may also influence variation along Axis $2(P=0.055)$. Bulk density and organic matter concentrations in $0-15 \mathrm{~cm}$ mineral soils are not significantly related to vegetation variation along the DCA ordination axes (Table 6).

Multiple regression analyses and field observations suggest that vegetation composition is related to fire history. Although fire has been widespread on the plain, it has not been uniform among vegetation types. Soil charcoal, stem charring, or fire scars were recorded in $83 \%$ of sample plots, including $100 \%$ of unplowed and $78 \%$ of plowed plots. Evidence of fire was observed in $100 \%$ of plots in Types 5, 6, and 7, 82\% of Type 2 , and $90 \%$ of Type 3 plots. We found no evidence of fire 
TABLE 3. Percent frequency of occurrence $(\%)$ and mean cover/abundance $(\bar{X})$ of species on the Montague Plain in seven vegetation types defined by TWINSPAN analysis. Species occurring in fewer than five plots are omitted. Nomenclature follows Seymour (1989). $n=$ number of plots.

\begin{tabular}{|c|c|c|c|c|c|c|c|c|c|c|c|c|c|c|}
\hline & \multicolumn{14}{|c|}{ Vegetation type $\dagger$} \\
\hline & \multicolumn{2}{|c|}{$(n=6)$} & \multicolumn{2}{|c|}{$\begin{array}{c}2 \\
(n=33)\end{array}$} & \multicolumn{2}{|c|}{$\begin{array}{c}3 \\
(n=40)\end{array}$} & \multicolumn{2}{|c|}{$\begin{array}{c}4 \\
(n=10)\end{array}$} & \multicolumn{2}{|c|}{$\begin{array}{c}5 \\
(n=11)\end{array}$} & \multicolumn{2}{|c|}{$\begin{array}{c}6 \\
(n=10)\end{array}$} & \multicolumn{2}{|c|}{$\begin{array}{c}7 \\
(n=11)\end{array}$} \\
\hline & $\%$ & $\bar{X}$ & $\%$ & $\bar{X}$ & $\%$ & $\bar{X}$ & $\%$ & $\bar{X}$ & $\%$ & $\bar{X}$ & $\%$ & $\bar{X}$ & $\%$ & $\bar{X}$ \\
\hline \multicolumn{15}{|l|}{ Trees $(>2.54 \mathrm{~cm} \mathrm{dbh})$} \\
\hline Populus tremuloides & 83 & 11 & 33 & 1 & 3 & 1 & & & & & 10 & 1 & & \\
\hline Populus grandidentata & 50 & 10 & 21 & 8 & 13 & 3 & & & & & 10 & 1 & & \\
\hline Betula populifolia & 83 & 2 & 100 & 4 & 95 & 2 & 50 & 1 & 9 & 1 & & & 9 & 1 \\
\hline Pinus sylvestris & & & 6 & 1 & 5 & 1 & 10 & 1 & & & & & & \\
\hline Pinus rigida & 83 & 5 & 97 & 27 & 100 & 54 & 100 & 24 & 55 & 5 & 80 & 24 & 36 & 15 \\
\hline Pinus strobus & 50 & 1 & 52 & 1 & 65 & 6 & 100 & 28 & 27 & 4 & 10 & 1 & & \\
\hline Prunus serotina & 83 & 1 & 58 & 1 & 20 & 1 & 40 & 1 & 9 & 1 & 20 & 2 & 45 & . 1 \\
\hline Quercus coccinea & 33 & 1 & 85 & 5 & 63 & 4 & 100 & 12 & 100 & 36 & 80 & 8 & & \\
\hline Acer rubrum & 17 & 1 & 58 & 1 & 38 & 1 & 90 & 2 & 100 & 6 & 100 & 2 & 27 & 1 \\
\hline Amelanchier spp. & & & 27 & 1 & 5 & 1 & 20 & 1 & 64 & 1 & 50 & 1 & 36 & 1 \\
\hline Quercus alba & 33 & 1 & 12 & 3 & 20 & 1 & 40 & 4 & 27 & 4 & 40 & 1 & 9 & 1 \\
\hline Quercus velutina & 17 & 1 & 3 & 2 & 20 & 1 & 30 & 4 & 9 & 10 & 20 & 6 & & \\
\hline Betula papyrifera & & & & & 5 & 1 & 20 & 3 & 9 & 2 & & & & \\
\hline Quercus rubra & & & 3 & 1 & 15 & 3 & 60 & 5 & 27 & 2 & 20 & 2 & & \\
\hline Castanea dentata & & & 3 & 1 & & & 20 & 1 & 36 & 1 & 10 & 1 & & \\
\hline \multicolumn{15}{|l|}{ Shrubs and saplings $<2.54 \mathrm{~cm} \mathrm{dbh}$} \\
\hline Cornus racemosa & 67 & 3 & & & & & & & & & 10 & 1 & & \\
\hline Juniperus communis & 50 & 1 & 6 & 1 & 5 & 1 & & & & & & & & \\
\hline Ceanothus americanus & 33 & 2 & 9 & 2 & 5 & 1 & & & & & & & & \\
\hline Spiraea latifolia & 83 & 2 & 21 & 5 & 15 & 1 & 10 & 1 & & & 10 & 1 & & \\
\hline Spiraea tomentosa & 50 & 2 & 6 & 3 & & & & & & & & & & \\
\hline Populus tremuloides & 100 & 7 & 52 & 4 & 13 & 1 & 10 & 1 & & & & & 45 & 1 \\
\hline Quercus velutina & & & & & 33 & 3 & & & & & 10 & 1 & 9 & 1 \\
\hline Vaccinium corymbosum & 17 & 2 & 30 & 2 & 15 & 2 & & & & & 10 & 2 & & \\
\hline Vaccinium stamineum & 17 & 3 & 12 & 2 & 10 & 3 & 10 & 1 & & & & & & \\
\hline Prunus pensylvanica & 33 & 3 & 45 & 3 & 10 & 1 & 10 & 1 & & & 10 & 2 & 36 & 2 \\
\hline Rubus spp. & 100 & 3 & 97 & 3 & 55 & 2 & 50 & 1 & & & 20 & 3 & 9 & 3 \\
\hline Betula populifolia & 100 & 2 & 100 & 5 & 98 & 5 & 70 & 2 & 27 & 2 & & & 9 & 2 \\
\hline Pinus rigida & 100 & 2 & 73 & 2 & 80 & 3 & 10 & 1 & 55 & 1 & 20 & 1 & 18 & 2 \\
\hline Quercus alba & 67 & 3 & 48 & 2 & 60 & 2 & 90 & 2 & 55 & 2 & 50 & 2 & 18 & 3 \\
\hline Pinus strobus & 83 & 3 & 97 & 3 & 93 & 3 & 100 & 9 & 100 & 2 & 80 & 1 & 9 & 1 \\
\hline Prunus serotina & 100 & 2 & 97 & 3 & 75 & 2 & 90 & 2 & 64 & 2 & 100 & 2 & 91 & 3 \\
\hline Quercus coccinea & 67 & 8 & 91 & 3 & 78 & 5 & 80 & 4 & 82 & 3 & 80 & 2 & 36 & 1 \\
\hline Comptonia peregrina & 50 & 5 & 94 & 4 & 43 & 2 & 20 & 1 & & & 80 & 2 & 91 & 11 \\
\hline Prunus pumila & 33 & 2 & 33 & 2 & 5 & 2 & & & & & & & 45 & 3 \\
\hline Rosa carolina & 17 & 1 & 9 & 1 & 5 & 1 & & & & & & & 18 & 2 \\
\hline Corylus americana & 17 & 3 & 12 & 2 & 3 & 2 & & & 9 & 1 & & & 9 & 3 \\
\hline Populus grandidentata & 50 & 5 & 3 & 2 & 5 & 1 & & & & & 20 & 2 & & \\
\hline Salix humilis & 67 & 2 & 21 & 1 & 3 & 2 & 10 & 1 & & & & & 27 & 1 \\
\hline Quercus ilicifolia & 100 & 2 & 100 & 20 & 98 & 11 & 80 & 7 & 82 & 7 & 100 & 56 & 100 & 52 \\
\hline Vaccinium angustifolium & 67 & 2 & 88 & 11 & 98 & 11 & 80 & 5 & 100 & 13 & 90 & 21 & 100 & 57 \\
\hline Acer rubrum & 67 & 2 & 85 & 4 & 80 & 2 & 100 & 4 & 100 & 6 & 100 & 5 & 82 & 3 \\
\hline Amelanchier spp. & 83 & 2 & 91 & 2 & 60 & 2 & 90 & 2 & 100 & 3 & 100 & 3 & 91 & 4 \\
\hline Vaccinium vacillans & 17 & 3 & 82 & 3 & 90 & 3 & 80 & 3 & 100 & 10 & 100 & 10 & 100 & 8 \\
\hline Carya glabra/ovalis & 17 & 2 & 9 & 1 & 3 & 2 & 20 & 1 & 9 & 1 & & & & \\
\hline Tsuga canadensis & 17 & 1 & 6 & 1 & 5 & 1 & 20 & 1 & 18 & 1 & & & & \\
\hline Viburnum acerifolium & 33 & 1 & 3 & 2 & 8 & 1 & 40 & 1 & 45 & 2 & 20 & 1 & & \\
\hline Quercus rubra & & & 3 & 2 & 13 & 5 & 40 & 3 & 36 & 2 & 10 & 1 & & \\
\hline Castanea dentata & & & 3 & 3 & 3 & 1 & 40 & 3 & 55 & 2 & 20 & 1 & & \\
\hline Quercus prinoides & 33 & 1 & 45 & 4 & 28 & 2 & 30 & 2 & 100 & 3 & 100 & 8 & 100 & 14 \\
\hline Aronia sp. & 17 & 1 & 21 & 5 & 3 & 2 & & & 9 & 3 & 80 & 3 & 82 & 9 \\
\hline Gaylussacia baccata & & & 9 & 1 & 23 & 2 & 60 & 4 & 91 & 37 & 80 & 21 & 45 & 2 \\
\hline Kalmia angustifolia & & & 3 & 2 & 5 & 2 & & & 55 & 3 & 40 & 5 & 27 & 5 \\
\hline Gaultheria procumbens & & & 3 & 3 & & & 20 & 1 & 91 & 6 & 80 & 8 & 91 & 8 \\
\hline Viburnum cassinoides & & & 15 & 1 & 8 & 2 & 20 & 1 & 55 & 1 & 70 & 2 & 73 & 4 \\
\hline Herbs & & & & & & & & & & & & & & \\
\hline Hypericum perforatum & 100 & 2 & & & & & & & & & & & & \\
\hline Lespedeza $\mathrm{sp}$. & 83 & 2 & & & & & & & & & & & & \\
\hline Potentilla simplex & 83 & 3 & 6 & 1 & 3 & 1 & & & & & 10 & 1 & & \\
\hline Rumex acetosella & 67 & 2 & 12 & 2 & 3 & 2 & & & & & & & & \\
\hline
\end{tabular}




\begin{tabular}{|c|c|c|c|c|c|c|c|c|c|c|c|c|c|c|}
\hline & \multicolumn{14}{|c|}{ Vegetation type } \\
\hline & \multicolumn{2}{|c|}{$(n=6)$} & \multicolumn{2}{|c|}{$\begin{array}{c}2 \\
(n=33)\end{array}$} & \multicolumn{2}{|c|}{$(n=40)$} & \multicolumn{2}{|c|}{$\begin{array}{c}4 \\
(n=10)\end{array}$} & \multicolumn{2}{|c|}{$\begin{array}{c}5 \\
(n=11)\end{array}$} & \multicolumn{2}{|c|}{$\begin{array}{c}6 \\
(n=10)\end{array}$} & \multicolumn{2}{|c|}{$\begin{array}{c}7 \\
(n=11)\end{array}$} \\
\hline & $\%$ & $\bar{X}$ & $\%$ & $\bar{X}$ & $\%$ & $\overline{\bar{X}}$ & $\%$ & $\bar{X}$ & $\%$ & $\overline{\bar{X}}$ & $\%$ & $\overline{\bar{X}}$ & $\%$ & $\bar{X}$ \\
\hline Solidago juncea & 100 & 3 & 15 & 1 & 3 & 1 & & & & & 10 & 1 & & \\
\hline Danthonia spicata & 100 & 5 & 64 & 3 & 30 & 2 & & & 9 & 3 & 10 & & 18 & 2 \\
\hline Solidago rugosa & 67 & 4 & 21 & 2 & & & & & & & & & & \\
\hline Andropogon scoparius & 100 & 59 & 94 & 10 & 83 & 3 & & & & & 20 & 2 & 18 & 2 \\
\hline Cladonia spp. & 33 & 1 & 6 & 2 & 15 & 1 & & & & & 10 & 1 & & \\
\hline Monotropa hypopithys & & & 6 & 1 & 60 & 2 & & & & & & & & \\
\hline Cladonia cristatella & 17 & 1 & 27 & 1 & 13 & 1 & & & & & & & 9 & 1 \\
\hline Lycopodium clavatum & & & 9 & 5 & 5 & 3 & & & & & & & & \\
\hline Apocynum androsaemifolium & 33 & 3 & 73 & 2 & 43 & 1 & 30 & 1 & & & 20 & 1 & 27 & 2 \\
\hline Panicum spp. & 33 & 2 & 21 & 1 & & & & & 9 & 1 & 10 & 1 & & \\
\hline Polytrichum spp. & 83 & 5 & 100 & 21 & 100 & 27 & 90 & 2 & 27 & 1 & 10 & 2 & 45 & 2 \\
\hline Cypripedium acaule & 33 & 1 & 91 & 2 & 80 & 2 & 90 & 2 & 45 & 1 & 40 & 2 & 18 & 1 \\
\hline Melampyrum lineare & 67 & 1 & 97 & 2 & 98 & 2 & 40 & 2 & 36 & 1 & 40 & 2 & 82 & 2 \\
\hline Chimaphila umbellata & 33 & 2 & & & 5 & 3 & 10 & 3 & & & & & & \\
\hline Chimaphila maculata & 33 & 1 & 6 & 1 & 15 & 1 & 20 & 1 & & & & & & \\
\hline Other moss & 50 & 2 & 33 & 2 & 58 & 2 & 100 & 2 & 36 & 2 & & & 18 & 1 \\
\hline Carex pensylvanica & 67 & 7 & 94 & 8 & 73 & 4 & 60 & 3 & 100 & 4 & 100 & 3 & 100 & 4 \\
\hline Lycopodium obscurum & 50 & 1 & 55 & 3 & 35 & 2 & 40 & 3 & 36 & 2 & 60 & 2 & 27 & 3 \\
\hline Maianthemum canadense & 33 & 1 & 45 & 2 & 18 & 2 & 40 & 3 & 18 & 2 & 10 & 2 & & \\
\hline Lysimachia quadrifolia & 100 & 3 & 100 & 3 & -40 & 1 & 30 & 1 & 36 & 1 & 70 & 2 & 82 & 2 \\
\hline Smilacina racemosa & & & 9 & 1 & 5 & 1 & & & & & 10 & 2 & 9 & 2 \\
\hline Pteridium aquilinum & & & 45 & 13 & 40 & 6 & 70 & 5 & 82 & 5 & 90 & 6 & 82 & 3 \\
\hline Monotropa uniflora & & & 15 & 1 & 15 & 1 & 60 & 1 & 9 & 1 & 20 & 1 & & \\
\hline Unknown dicot & 33 & 2 & 9 & 1 & 3 & 1 & 20 & 1 & 9 & 2 & & & & \\
\hline $\begin{array}{l}\text { Lycopodium complanatum/ } \\
\text { tristachyum }\end{array}$ & 17 & 1 & 24 & 2 & 3 & 3 & 50 & 8 & 18 & 3 & 10 & 2 & 9 & 1 \\
\hline Mitchella repens & 17 & 1 & 6 & 1 & & & 10 & 3 & 9 & 2 & & & & \\
\hline Trientalis borealis & & & 9 & 1 & 3 & 2 & 40 & 2 & 27 & 3 & & & & \\
\hline Unknown grass & 17 & 2 & & & 8 & 1 & & & & & & & 27 & 1 \\
\hline Oryzopsis pungens & & & & & & & & & & & 10 & 1 & 45 & 2 \\
\hline Comandra umbellata & & & 3 & 2 & & & & & & & 10 & 1 & 36 & 2 \\
\hline Lilium philadelphicum & & & & & & & & & & & & & 45 & 1 \\
\hline
\end{tabular}

$\dagger$ Mean species richness for each vegetation type (ranges are given in parentheses): (1) 45 (28-66); (2) 28 (20-36); (3) 22 (13-33); (4) 24 (18-32); (5) 21 (15-30); (6) 22 (17-26); (7) 21 (15-31).

in any of Type 1 plots, perhaps in part as a result of our limited ability to detect fires in areas dominated by herbaceous vegetation. Evidence of fire occurred in $50 \%$ of Type 4 plots $(n=10)$, with only white pine and scrub oak showing consistent patterns of abundance with respect to presence or absence of fire. White pine is more abundant (mean basal area $=19.7 \mathrm{~m}^{2} / \mathrm{ha}$; mean density/ha $=890$ ) in plots with no evidence of fire than in those that have burned (mean basal area = $2.5 \mathrm{~m}^{2} / \mathrm{ha}$; mean density/ha $=220$ ), whereas scrub oak is more frequent and abundant in plots that have burned (frequency $=1.0$; mean cover $=6.2 \%$ ) than in those for which we found no evidence of fire (frequency = 0.6 ; mean cover $=1.8 \%$ ).

The importance of prior land use (i.e., plowing) in determining modern vegetation patterns is suggested by the results of multiple regression analyses. To explore this relationship further, we examined the distribution patterns of individual plant species with respect to patterns of historical land uses (Fig. 8). Whereas some species are equally frequent on formerly plowed vs. unplowed sites, the distribution of many species is strongly related to prior land use. For instance, Gaul- theria procumbens occurs on $96 \%$ of the plots sampled in unplowed areas, but on only $5 \%$ of formerly plowed plots. Similarly, Gaylussacia baccata occurs on nearly $80 \%$ of unplowed but only $21 \%$ of plowed plots. In contrast, Polytrichum spp. and Betula populifolia are present on $>90 \%$ of plots that were plowed, but on $<20 \%$ of unplowed sites.

For many species, cover abundance is strikingly different on sites of different land use (Figs. 9-10), even when the frequency of occurrence is similar. For instance, Quercus ilicifolia and Vaccinium angustifolium occur with nearly equal frequency on different landuse types (Fig. 8), but are more abundant on sites that have never been plowed (Fig. 9).

\section{DisCUSSION}

The interpretation of historical impacts on modern vegetation is often confounded by the correlation of physical environment with land use and vegetation. We selected Montague Plain for investigation in part because it appeared homogeneous with respect to topography, drainage, and soil texture. We anticipated that such conditions would enable detection of land-use and 
disturbance effects on vegetation without confounding effects of differing initial site conditions. Physical and chemical soil analyses confirm our preliminary observations that the plain is edaphically homogeneous. All soils are classified in two very similar soil series, with little variability in texture, drainage, or chemistry. The limited variability in soil characteristics is reasonably attributed to historical disturbances rather than to initial site conditions.

Land use on the plain followed historically established ownership boundaries and was not dictated by site quality. Although a few unplowed sites (9\% of unplowed pits) are perhaps sufficiently gravelly to have discouraged plowing, most are very similar to plowed areas with respect to soil texture. In most cases, the decision to plow a particular parcel was apparently a consequence of landowner discretion rather than a response to site suitability.

\section{Land-use history}

Historical accounts suggest that extraction of forest products was the primary land use on Montague Plain during the 18 th and early 19 th centuries. This is consistent with records from other sand plains across the northeastern United States (Wacker 1979, Milne 1985). Pitch pine forests in the Connecticut Valley were widely "boxed" for tar and turpentine production, with legislation regulating these activities as early as the late 17th century (Judd 1905, Hawes 1923). Pitch pine was also an important fuel for homes and by the mid-19th century was used extensively in Massachusetts as fuel for locomotives (Bromley 1935). It is likely, therefore, that forestry activities on Montague Plain through the 19 th century included products other than timber.

Despite the perception of sand plains as poor agricultural sites, the widespread use that we document in the 19th century is not unique to Montague Plain. In the Connecticut Valley of Massachusetts, nearly all modern pitch pine stands occur on formerly plowed sites (G. Motzkin and W. A. Patterson III, unpublished data), and several sand plains remain partially in agriculture today. Cultivation of similar sand plains occurred throughout the Northeast (Collins 1909, Howe 1910, Harshberger 1916, Olmsted 1937, Wacker 1979, Olsvig 1980, Patterson et al. 1984, Milne 1985, Backman and Patterson 1988, Seischab and Bernard 1991).

Determining the land-use history of unplowed sites on the plain is problematical because of lack of historical references. We hypothesize that unplowed areas were used primarily as woodlots or unimproved pastures, and that differences in fire and cutting history have influenced modern vegetation structure and composition. Scrub oak stands (Types 6 and 7) were probably forested in the past; repeated cutting and burning may have led to shrubland development by removing overstory trees and stimulating vigorous sprouting of scrub oak (Harshberger 1916, Olmsted 1937, Milne 1981). The notion that scrub oak stands developed in areas of former woodlots is suggested by H. D. Thoreau (Torrey and Allen 1962:294) who, in 1851, observed:

the edge of a wood-lot ... where ... shrub oaks bounded on a neighbors' small pitch pines, which grew very close together... The line of separation was remarkably straight and distinct, neither a shrub oak nor a pine passing its limit, the ground where the pines grew having apparently been cultivated so far, and its edges defined by the plow.

Of interest are the fact that Thoreau refers to the shrub oak stand as a woodlot and the observation that scrub oaks had not yet spread onto the abandoned field that contained pitch pine. Our results indicate that many decades after agricultural abandonment scrub oak has dispersed onto most formerly plowed sites (Fig. 8), but as scattered individuals rather than the dense stands found on unplowed areas (Fig. 9).

Modern scrub oak stands may also have developed on former pastures, a pattern that is widespread in coastal New England (Dunwiddie 1992; W. A. Patterson III, personal communication). Because nearly all scrub oak stands on the plain were extant in 1939, pasture abandonment may have occurred in the 19th century prior to widespread use of barbed wire. This may explain the lack of barbed wire in these stands.

\section{The soil legacy of land use}

In the early 19th century, Dwight (1821) described the Montague Plain and surrounding areas as "an extensive yellow pine plain covered with a lean, miserable soil." Agriculture subsequent to Dwight's visit had a major impact on vegetation but a limited, primarily physical long-term effect on soils. Although visually striking, differences between plowed and unplowed A horizons (Fig. 6) are primarily a coloring effect produced by the redistribution of organic matter within the mineral soil as a result of plowing (Table 4). We document a small but significant increase in soil organic matter mass on plowed sites but interpret this as a consequence of a minor increase in bulk density resulting from soil compaction by plowing rather than an increase resulting from agricultural amendments. This interpretation is supported by the lack of difference in $0-30 \mathrm{~cm}$ organic matter concentrations on plowed vs. unplowed sites and by the lack of additional indication of agricultural amendments (however, see vegetation Type 1). Organic matter concentration and bulk density influence soil moisture holding capacity, which may in turn affect plant survivorship and growth (Thihatmer 1989; Prévost and Bolghari 1990). However, soil moisture holding capacity does not differ between plowed and unplowed sites on Montague Plain (A. Allen, unpublished data), suggesting that reduced holding capacity associated with lower organic matter concentrations in $0-15 \mathrm{~cm}$ cultivated sites may be offset by increased capacity of the compacted soil (Hillel 1982). 


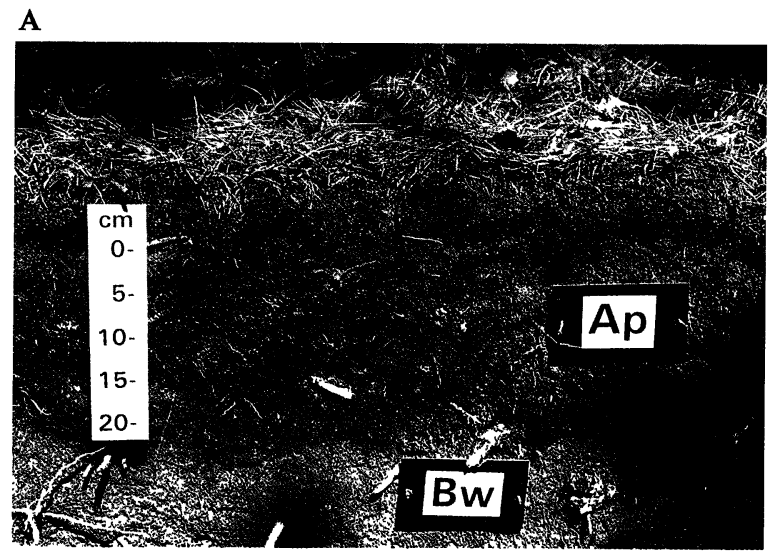

TABLE 4. Montague Plain mineral soil properties grouped by historical land use. Values are means and $t$-test $P$ values. $n=$ number of soil pits sampled for each property in each land-use type.

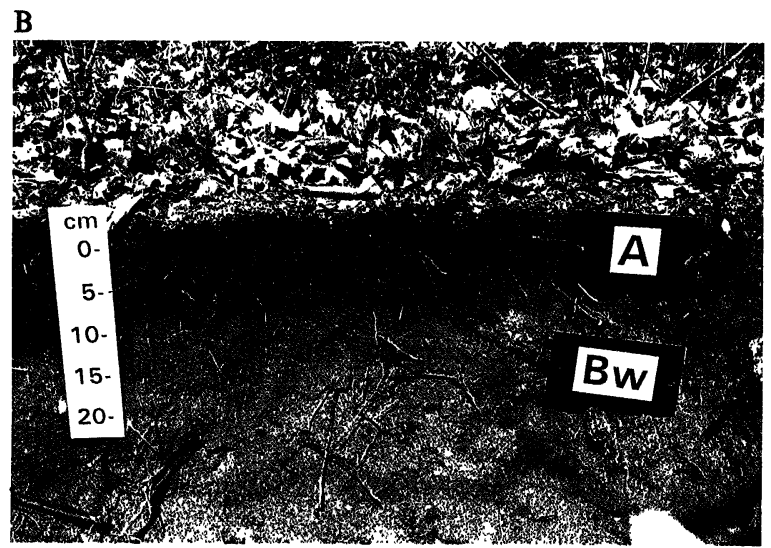

\begin{tabular}{lrcc}
\hline \hline & $\begin{array}{c}\text { Culti- } \\
\text { vated }\end{array}$ & $\begin{array}{c}\text { Unculti- } \\
\text { vated }\end{array}$ & $P$ \\
\hline Exchangeable cations & $(n=46)$ & $(n=20)$ & \\
0-15 cm depth & & & \\
Potassium (mg/kg) & 20.84 & 25.60 & 0.025 \\
Magnesium (mg/kg) & 6.13 & 6.07 & 0.943 \\
Calcium (mg/kg) & 26.99 & 17.50 & 0.202 \\
Other properties & $(n=188)$ & $(n=54)$ & \\
0-15 cm depth & & & \\
Organic matter $(\%)$ & 4.68 & 5.22 & 0.003 \\
Bulk density $\left(\mathrm{g} / \mathrm{cm}^{3}\right)$ & 1.05 & 0.96 & 0.000 \\
pH & 4.49 & 4.45 & 0.232 \\
Coarse fragments $(\%)$ & 4.94 & 5.13 & 0.802 \\
15-30 cm depth & & & \\
Organic matter $(\%)$ & 2.63 & 2.27 & 0.003 \\
Bulk density (g/cm $\left.{ }^{3}\right)$ & 1.24 & 1.20 & 0.016 \\
pH & 4.71 & 4.74 & 0.364 \\
0-30 cm depth & & & \\
Organic matter $(\mathrm{Mg} / \mathrm{ha})$ & 60.06 & 56.14 & 0.045 \\
Organic matter $(\%)$ & 3.64 & 3.73 & 0.576 \\
\hline
\end{tabular}

FIG. 6. Plowed (A) and unplowed (B) surface soil horizons on Montague Plain indicating differences in color, depth, and boundary type. Ap = plow horizon, $\mathrm{Bw}=$ minimally weathered subsoil horizon.

Higher potassium levels on unplowed vs. plowed sites (Table 4) are largely a result of high levels in scrub oak stands (Types 6 and 7; Table 5). This may indicate: (1) differences in the amount of potassium stored in the soil vs. the aboveground biomass in stands of differing structure, (2) potassium enrichment on frequently burned sites, or (3) nutrient depletion of for-

merly plowed sites. Because mean potassium levels are highest in stand types with low tree basal area (i.e., Types 7, 6, 1, and 2), regardless of land use, we suspect that soil vs. aboveground biomass distribution may largely account for the differences observed (Chapin and Van Cleve 1978, Boerner 1982, Rapp 1983). This interpretation is consistent with the observation that long-lasting agricultural depletion of $\mathrm{K}$ is not expected because of the potential for replenishment from primary minerals along with low background $\mathrm{K}$ levels and low leaching rates in sandy, siliceous soils (Pritchett 1979, Binkley 1986, Troeh and Thompson 1993). In addition, mineralizable nitrogen, an associated macronutrient, does not differ on plowed vs. unplowed sites (J. Compton and R. Boone, unpublished data) and pitch pine growth rates do not differ by land use (G. Motzkin and A. Allen, unpublished data).

FIG. 7. Cross-sectional diagram of vegetation patterns and soil features at boundary between plowed and unplowed sites. $\mathrm{A}=$ unplowed surface horizon, Ap = plow horizon, $\mathrm{Bw}=$ minimally weathered subsoil horizon.

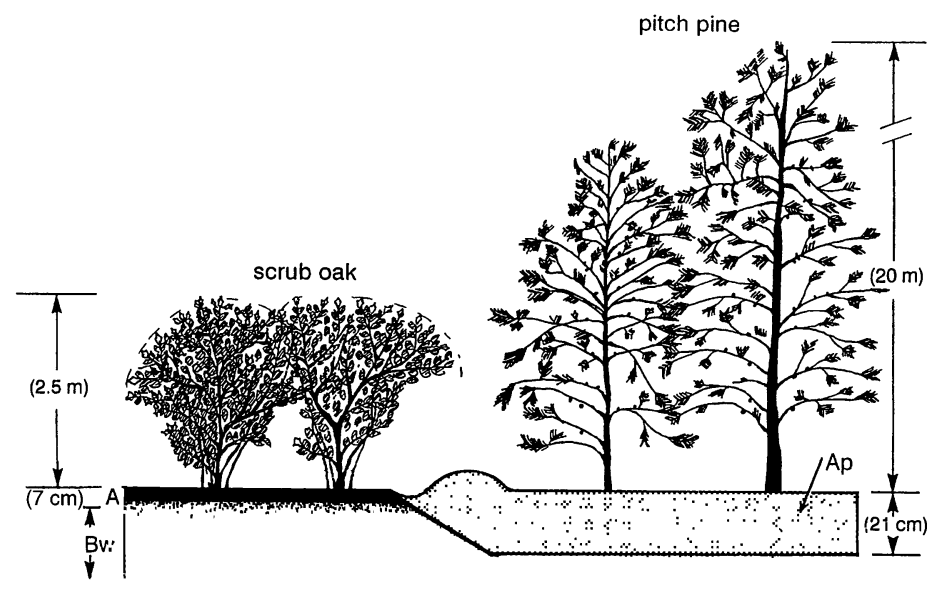


TABle 5. Probability of difference (95\% confidence) using Kruskal-Wallis one-way ANOVA for Montague Plain mineral soil property medians grouped by the seven vegetation types defined by TWINSPAN analysis. Similar letters within rows indicate no significant difference between medians. $n=$ number of soil pits sampled for each property in each vegetation type.

\begin{tabular}{|c|c|c|c|c|c|c|c|}
\hline & \multicolumn{7}{|c|}{ Vegetation type } \\
\hline & 1 & 2 & 3 & 4 & 5 & 6 & 7 \\
\hline Exchangeable cations & $(n=4)$ & $(n=16)$ & $(n=20)$ & $(n=6)$ & $(n=6)$ & $(n=6)$ & $(n=8)$ \\
\hline $\begin{array}{l}\text { 0-15 cm depth } \\
\text { Potassium }(\mathrm{mg} / \mathrm{kg}) \\
\text { Magnesium }(\mathrm{mg} / \mathrm{kg}) \\
\text { Calcium }(\mathrm{mg} / \mathrm{kg})\end{array}$ & $\begin{array}{c}22.34^{\mathrm{abc}} \\
10.58^{\mathrm{a}} \\
103.08^{\mathrm{a}}\end{array}$ & $\begin{array}{l}23.05^{\mathrm{abc}} \\
6.56^{\mathrm{b}} \\
23.02^{\mathrm{b}}\end{array}$ & $\begin{array}{r}18.91^{\mathrm{a}} \\
4.63^{\mathrm{c}} \\
15.05^{\mathrm{b}}\end{array}$ & $\begin{array}{c}19.63^{\mathrm{ab}} \\
4.37^{\mathrm{bc}} \\
12.33^{\mathrm{b}}\end{array}$ & $\begin{array}{c}18.06^{\mathrm{a}} \\
4.99^{\mathrm{bc}} \\
10.71^{\mathrm{b}}\end{array}$ & $\begin{array}{c}26.05^{\mathrm{bc}} \\
5.70^{\mathrm{bc}} \\
16.24^{\mathrm{b}}\end{array}$ & $\begin{array}{l}28.50^{\mathrm{c}} \\
6.65^{\mathrm{bc}} \\
25.10^{\mathrm{b}}\end{array}$ \\
\hline $\begin{array}{l}\text { Other properties } \\
0-15 \mathrm{~cm} \mathrm{depth}\end{array}$ & $(n=12)$ & $(n=66)$ & $(n=80)$ & $(n=20)$ & $(n=22)$ & $(n=20)$ & $(n=22)$ \\
\hline $\begin{array}{l}\text { Organic matter }(\%) \\
\text { Bulk density }\left(\mathrm{g} / \mathrm{cm}^{3}\right) \\
\mathrm{pH} \\
\text { Coarse fragments }(\%)\end{array}$ & $\begin{array}{l}3.54^{\mathrm{a}} \\
1.17^{\mathrm{a}} \\
5.05^{\mathrm{a}} \\
3.27^{\mathrm{a}}\end{array}$ & $\begin{array}{l}4.91^{\mathrm{bc}} \\
1.04^{\mathrm{c}} \\
4.50^{\mathrm{b}} \\
3.47^{\mathrm{a}}\end{array}$ & $\begin{array}{l}4.34^{\mathrm{a}} \\
1.07^{\mathrm{c}} \\
4.45^{\mathrm{b}} \\
4.53^{\mathrm{a}}\end{array}$ & $\begin{array}{l}4.54^{\mathrm{ac}} \\
1.08^{\mathrm{ac}} \\
4.42^{\mathrm{b}} \\
3.60^{\mathrm{a}}\end{array}$ & $\begin{array}{l}5.08^{\mathrm{bc}} \\
0.98^{\mathrm{b}} \\
4.45^{\mathrm{b}} \\
2.70^{\mathrm{a}}\end{array}$ & $\begin{array}{l}5.09^{\mathrm{bc}} \\
0.96^{\mathrm{b}} \\
4.37^{\mathrm{b}} \\
3.32^{\mathrm{a}}\end{array}$ & $\begin{array}{l}5.41^{\mathrm{b}} \\
0.95^{\mathrm{b}} \\
4.52^{\mathrm{b}} \\
3.96^{\mathrm{a}}\end{array}$ \\
\hline $\begin{array}{l}15-30 \mathrm{~cm} \text { depth } \\
\text { Organic matter }(\%) \\
\text { Bulk density }\left(\mathrm{g} / \mathrm{cm}^{3}\right) \\
\text { pH }\end{array}$ & $\begin{array}{l}2.34^{\mathrm{ab}} \\
1.30^{\mathrm{a}} \\
5.30^{\mathrm{a}}\end{array}$ & $\begin{array}{l}2.71^{\mathrm{a}} \\
1.25^{\mathrm{a}} \\
4.70^{\mathrm{b}}\end{array}$ & $\begin{array}{l}2.58^{\mathrm{ab}} \\
1.26^{\mathrm{a}} \\
4.68^{\mathrm{b}}\end{array}$ & $\begin{array}{l}2.39^{\mathrm{ab}} \\
1.28^{\mathrm{a}} \\
4.69^{\mathrm{b}}\end{array}$ & $\begin{array}{l}2.14^{\mathrm{b}} \\
1.21^{\mathrm{a}} \\
4.68^{\mathrm{b}}\end{array}$ & $\begin{array}{l}2.27^{\mathrm{ab}} \\
1.26^{\mathrm{a}} \\
4.73^{\mathrm{b}}\end{array}$ & $\begin{array}{l}2.31^{\mathrm{ab}} \\
1.24^{\mathrm{a}} \\
4.73^{\mathrm{b}}\end{array}$ \\
\hline $\begin{array}{l}0-30 \mathrm{~cm} \text { depth } \\
\text { Organic matter }(\mathrm{Mg} / \mathrm{ha}) \\
\text { Organic matter }(\%)\end{array}$ & $\begin{array}{r}53.64^{\mathrm{a}} \\
2.97^{\mathrm{a}}\end{array}$ & $\begin{array}{r}60.77^{\mathrm{a}} \\
3.61^{\mathrm{a}} \\
\end{array}$ & $\begin{array}{r}59.30^{\mathrm{a}} \\
3.39^{\mathrm{a}} \\
\end{array}$ & $\begin{array}{r}60.72^{\mathrm{a}} \\
3.38^{\mathrm{a}} \\
\end{array}$ & $\begin{array}{r}51.15^{\mathrm{a}} \\
3.20^{\mathrm{a}} \\
\end{array}$ & $\begin{array}{r}53.29^{\mathrm{a}} \\
3.23^{\mathrm{a}} \\
\end{array}$ & $\begin{array}{r}58.02^{\mathrm{a}} \\
3.79^{\mathrm{a}} \\
\end{array}$ \\
\hline
\end{tabular}

Soil $\mathrm{pH}$, and calcium and magnesium concentrations are remarkably similar among land uses and vegetation types, except for Type 1 where they are consistently higher (Table 5). Aerial photo analyses indicate that Type 1 occurs on sites cultivated more recently $(30-$ $50 \mathrm{yr}$ ago) than all other areas, and high $\mathrm{pH}$ and exchangeable $\mathrm{Ca}$ and $\mathrm{Mg}$ suggest that these sites were heavily limed. Based on the data of Brady (1990), sandy soils that are amended to $\mathrm{pH} 6.5$ should return

TABLE 6. Multiple regression of environmental variables (independent) vs. DCA ordination Axes 1 and 2 (dependent variables, tested separately). Organic matter and hydrogen ion concentrations and bulk density are for $0-15 \mathrm{~cm}$ mineral soils. Fire and Ap present are categorical variables.

\begin{tabular}{lrrrr}
\hline \hline & \multicolumn{3}{c}{ Mean } & \\
& df & square & \multicolumn{1}{c}{$F$} & $P$ \\
\hline Axis 1 $\left(R^{2}=0.61\right)$ & & & & \\
Model & 6 & 8.125 & 29.741 & 0.000 \\
Ap present & 1 & 25.978 & 95.093 & 0.000 \\
O depth & 1 & 2.179 & 7.976 & 0.006 \\
[H+] & 1 & 1.065 & 3.898 & 0.051 \\
Fire & 1 & 0.895 & 3.276 & 0.073 \\
Bulk density & 1 & 0.078 & 0.284 & 0.595 \\
Organic matter & 1 & 0.001 & 0.003 & 0.960 \\
Error & 114 & 0.273 & & \\
Axis 2 $\left(R^{2}=0.47\right)$ & & & & \\
Model & 6 & 3.321 & 16.848 & 0.000 \\
O depth & 1 & 6.577 & 33.368 & 0.000 \\
Fire & 1 & 2.901 & 14.721 & 0.000 \\
Ap present & 1 & 0.743 & 3.772 & 0.055 \\
Organic matter & 1 & 0.208 & 1.055 & 0.306 \\
Bulk density & 1 & 0.383 & 1.944 & 0.166 \\
[H+] & 1 & 0.023 & 0.114 & 0.736 \\
Error & 114 & 0.197 & & \\
\hline
\end{tabular}

to $\mathrm{pH} 4.5$ through leaching losses in $16 \mathrm{yr}$. The retention of high $\mathrm{pH}$ for at least twice this period on these sites may be explained by the abundance of aspens (Populus tremuloides and $P$. grandidentata), which are noted for their ability to retain higher levels of exchangeable cations relative to nonaspen stands on similar soil (Alban 1979, Ruark and Bockheim 1988, Bockheim and Jepsen 1991).

In summary, with the exception of Type 1, there is little indication of long-term depletion or enrichment of soils on Montague Plain as a result of historical agriculture. Rather, plowing apparently resulted in relatively minor long-term alteration of physical and chemical soil properties. These results strongly corroborate historical accounts suggesting that agriculture on the plain, although extensive, was of limited duration and intensity.

\section{Modern vegetation: the relative importance of land use and fire history}

Multiple regression analyses suggest that variation in vegetation is largely accounted for by disturbance history. Presence of an Ap horizon is the most important environmental variable along DCA Axis 1 and corresponds to a land-use gradient ranging from heavily disturbed, plowed soils (depth of Ap: $15.5-33 \mathrm{~cm}$ ) to largely undisturbed, unplowed soils (depth of A horizon $<10 \mathrm{~cm}$ ). Thickness of the $\mathrm{O}$ horizon, an important explanatory variable along DCA axes 1 and 2, is interpreted as a complex result of (1) time since severe disturbance by plowing or fire, (2) canopy closure, and (3) litter quality. For instance, recently abandoned plowed sites with grasslands or open Populus stands 


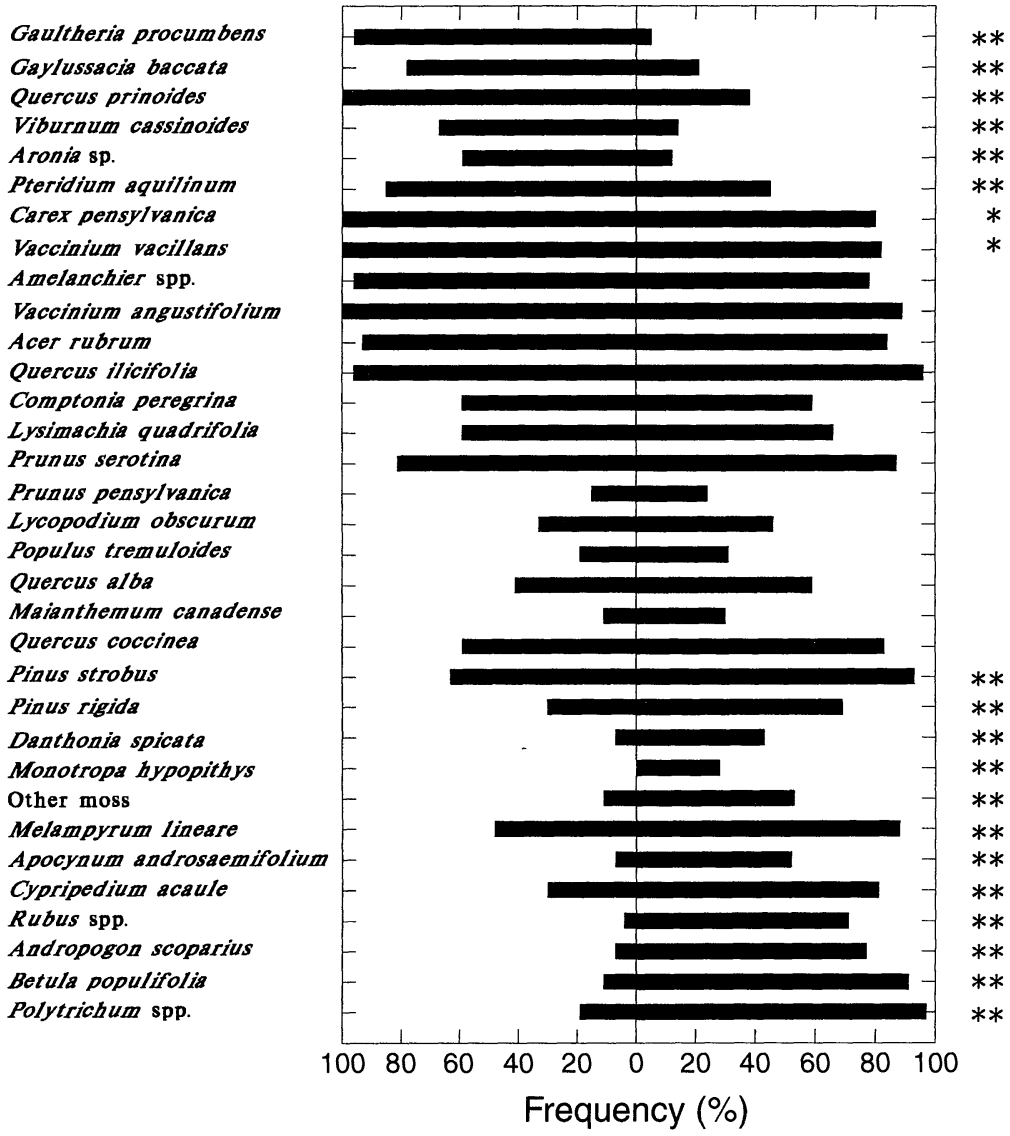

FIG. 8. Frequency of occurrence (\%) of common plant species on plowed vs. unplowed sites on Montague Plain. Only species occurring on at least 25 plots $(20 \%$ of total) are shown. Significance of $G$ tests is indicated at the $P<0.05(*)$ and $P<0.01(* *)$ levels after accounting for multiple comparisons.

(Type 1) have $O$ horizons $1-2 \mathrm{~cm}$ deep. Sites abandoned from agriculture $>50 \mathrm{yr}$ ago support pitch pine or pine-hardwood stands with $3-9 \mathrm{~cm}$ organic layers. On unplowed sites, deeper O layers occur in hardwoodhuckleberry (Type 5) stands lacking evidence of recent disturbance than in scrub oak stands that have recently burned.

Fire has been important on the Montague Plain, as demonstrated by high charcoal-to-pollen ratios (Table 1 ), numerous large fires during this century (Table 2), field evidence of fire in $83 \%$ of plots, and the relationship of fire to vegetation variability along DCA Axis 2 (Table 6). However, based on 20th century data (Table 2), the average return interval for fire at any location ("point frequency" sensu Forman and Boerner 1981 ) is quite long, particularly during the past several decades. In addition, most fires in this century have been low severity spring fires that have not consumed the soil organic layer.

Charcoal observed in or at the base of the $\mathrm{O}$ horizon on formerly plowed sites results from fires that occurred after agricultural abandonment, whereas char- coal on unplowed sites may persist from earlier periods. We interpret the lack of evidence of fire in plots in vegetation Type 1 as reflecting both our ability to detect fires and the actual fire histories of these sites. Sites supporting Type 1 were abandoned from agriculture in recent decades, a period when large fires have been infrequent, and so it is likely that some of these sites have not burned. However, our ability to detect fires early after abandonment, prior to dominance by woody vegetation that may leave persistent charcoal, is also quite limited. Thus, we failed to find evidence of fire on some Type 1 plots where we suspect fires have occurred.

The effects of fire on vegetation composition and structure apparently reflect species-specific responses to varied fire history across the plain. Based on field and historical evidence, we infer that fires during this century have: (1) influenced the rates and direction of vegetation change on both plowed and unplowed sites; and (2) influenced the abundance and composition of the understory (Little and Moore 1949, Buell and Cantlon 1953). However, unlike studies that identify fire (in 
Gaultheria procumbens

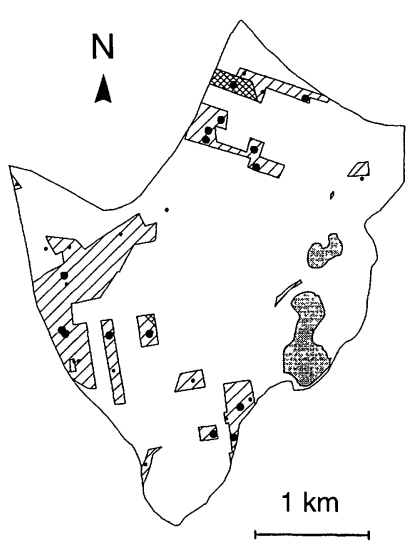

Vaccinium angustifolium

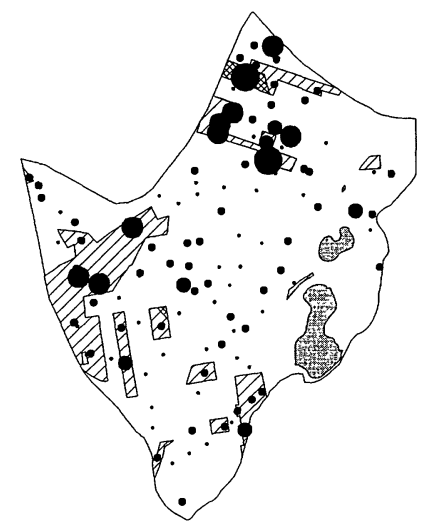

Gaylussacia baccata

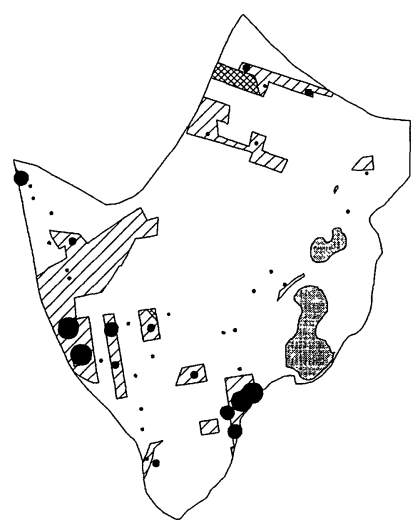

Quercus ilicifolia

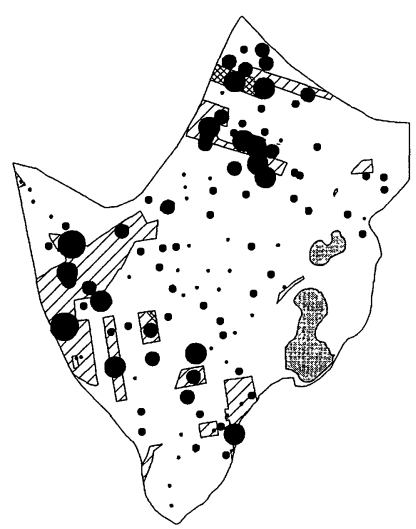

FIG. 9. Distribution and abundance of species characteristic of unplowed sites on Montague Plain. Relative abundance is indicated by the size of the dark circles. Ponds are shown in gray shading along the eastern edge of the plain. combination with cutting) as the primary determinant of modern vegetation patterns in northeastern sand plains (Lutz 1934, Buell and Cantlon 1950, Little 1964, Reiners 1965, Little 1979, Forman and Boerner 1981, Givnish et al. 1988), we suggest that fire influences vegetation composition and structure on Montague Plain within a pattern of species associations largely controlled by prior land use. Several examples are illustrative: (1) Pitch pine requires exposed mineral soil and open canopy conditions for successful establishment (Little and Garrett 1990), conditions that may be met through physical disturbance (e.g., plowing) or severe fire. Because few recent fires have been severe enough to create these conditions, nearly all extant pitch pine stands established on abandoned plowed fields; (2) After initial establishment, further establishment and dominance of pitch pine vs. other species is influenced by fire history. The high frequency of extensive fires early in this century (when most stands were establishing) probably favored pitch pine, which produces seed at a much younger age than hardwoods or white pine (Lutz 1934, Little 1964). Young white pine is more susceptible to fire than pitch pine and lacks the ability to resprout, which is shared by pitch pine and associated hardwood species. In the absence of fire, hardwoods and especially white pines increase (e.g., Type 4), whereas frequent light burns limit white pine and increase the sprout-hardwood understory while retaining a pitch pine overstory (Howe 1910, Little and Moore 1949, Little 1979, Milne 1985); (3) Vegetation structure on unplowed sites varies from closed canopy hardwood-huckleberry stands to dense scrub oak thickets. We suggest that repeated cutting and burning converted formerly forested areas into shrublands. Fire promotes the stability of scrub oak stands by removing developing tree canopies and by initiating vigorous sprouting of shrubs. In the absence of fire, hardwood trees slowly reestablish in scrub oak stands to form an open forest canopy. Scrub oak is shade intolerant, and the development of an overstory canopy leads to a reduction in its abundance (Whittaker and Woodwell 1968). Thus, the vegetation continuum on unplowed sites from scrub oak thickets to forested hardwood stands is apparently determined by fire and cutting history (Buell and Cantlon 1953, Reiners 1967).

In each of the above examples, fire history influences vegetation composition and structure, but the overall distinction between plowed and unplowed sites is retained. We suggest, therefore, that modern vegetation patterns on Montague Plain result from complex dis- 
FIG. 10. Distribution and abundance of species characteristic of plowed sites on Montague Plain. Relative abundance is indicated by the size of the dark circles. Ponds are shown in gray shading along the eastern edge of the plain.
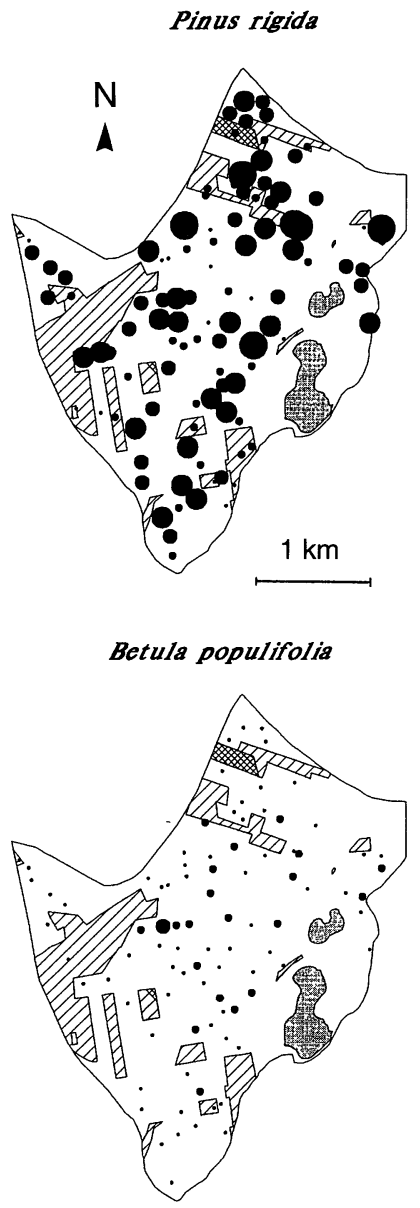

Polytrichum spp.

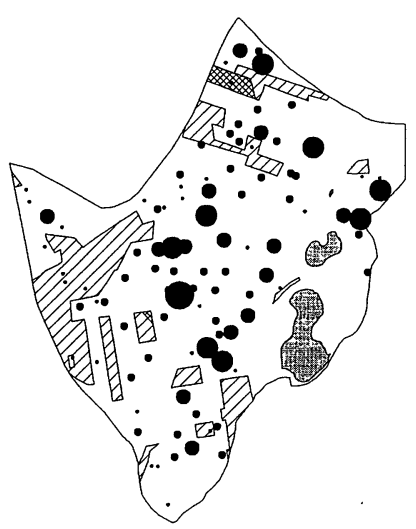

Andropogon scoparius

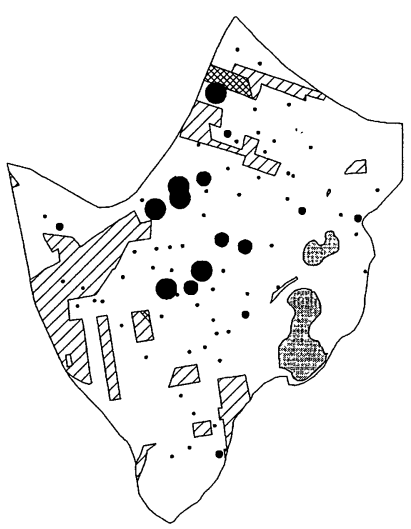

turbance histories, with fire serving to modify composition and structure of species assemblages that developed as a result of prior land use.

\section{Persistence of land-use influence on vegetation}

Plant species display a wide range of responses to historical land uses on Montague Plain. Many species are equally frequent and abundant on plowed vs. unplowed sites and successfully recolonize abandoned agricultural sites within several decades. Numerous weedy or early successional species are more frequent or abundant on formerly plowed sites, suggesting that they thrive under open and disturbed conditions and may persist for $>50 \mathrm{yr}$. Of particular interest is a group of species that is most frequent or abundant on unplowed sites. Once removed from a site by plowing these species are extremely slow to recolonize and may be absent or uncommon for 50 to $>100 \mathrm{yr}$ after field abandonment. Similar patterns occur on other Connecticut Valley sand plains (Olmsted 1937; G. Motzkin, personal observation), and in diverse communities in Europe (Wells et al. 1976, Peterken and Game 1984, Hermy et al. 1993) and eastern North America (Whitney and Foster 1988, Matlack 1994).

Human impacts on vegetation patterns on Montague
Plain are particularly interesting because these patterns have persisted for decades and, in some cases, for more than a century. Such long-lasting impacts may potentially result from a variety of mechanisms including: (1) species response to agricultural modification of edaphic characteristics, (2) biotic factors (e.g., dispersal and establishment limitations; shifts in competitive or plant-herbivore interactions, and other factors) in the absence of significant site modification, or (3) interactions between edaphic and biotic mechanisms.

The absence of long-lasting agricultural modification of edaphic properties suggests that the persistence of land-use/vegetation patterns on the plain is largely a consequence of biotic mechanisms. Striking vegetational differences between plowed and unplowed sites on Montague Plain (Figs. 4, 7-10) may result primarily from differential dispersal and establishment among plant species. For instance, pitch pine dominance on formerly plowed sites and absence from many unplowed areas apparently relates to its requirement for exposed mineral soil and open canopy conditions for germination and establishment (Little and Garrett 1990). We suspect that many species characteristic of unplowed sites (e.g., Gaultheria and Gaylussacia) were widespread throughout the plain prior to their removal 
by plowing, but that recolonization after agricultural abandonment has been greatly delayed by dispersal or establishment requirements. Most of these species produce abundant fruit and it is unlikely that seed production is limiting (Matlack and Good 1990). We hypothesize that limitations to successful reestablishment may be related to moisture on this drought-prone site. This hypothesis is consistent with the observation that species characteristic of unplowed sites on Montague Plain (e.g., Gaultheria procumbens, Viburnum cassinoides and others) are widely distributed on former pastures, plowed sites, and historical woodlots in more mesic sites (D. R. Foster, unpublished data). In addition, some of these species (e.g., Gaylussacia) are reported to be slower to recolonize xeric than mesic sites after agricultural abandonment of other northeastern sand plains (Little 1979). Dispersal and establishment limitations may also result from species responses to vegetation patterns that developed soon after agricultural abandonment. Although we document little longterm alteration of soil properties as a result of historical agriculture, short-term resource alteration may have influenced early successional patterns. Biotic conditions created by the species that were successful at early colonization of abandoned agricultural lands (e.g., pitch pine) may continue to limit the ability of species characteristic of unplowed sites to become established on formerly plowed areas. Interestingly, vegetative colonization of former agricultural fields is also extremely limited despite the well-documented ability of many of these species to reproduce clonally in response to disturbance (Niering and Dreyer 1989, Matlack et al. 1993). For instance, in the 50 to $>100$ yr since agricultural abandonment, Gaultheria and Gaylussacia have typically spread vegetatively only several metres onto formerly plowed areas. This has resulted in the persistence of very distinct vegetation boundaries between formerly plowed and unplowed sites.

The persistence of land-use effects on subsequent vegetation on Montague Plain may also be influenced by plant-herbivore interactions. The plain and other xeric sites apparently experience high levels of defoliation by gypsy moth larvae (Lymantria dispar) more frequently than nearby mesic sites (G. Motzkin, personal observation). Preferential herbivory of Quercus and other broad-leaved deciduous species may retard hardwood replacement of pitch pine on abandoned fields and, where mortality occurs, alter fuel loadings on both plowed and unplowed sites. The long-term influence of these and other plant-herbivore interactions on rates of succession on northeastern sand plains is poorly understood.

\section{Conservation implications}

Montague Plain and other large sand plains are considered high priorities for conservation throughout the northeastern United States because they support uncommon species and communities and are highly threatened by development (Schweitzer and Rawinski 1988). We have demonstrated that vegetation patterns on Montague Plain have been extremely dynamic over the past century, including major compositional and structural transformations associated with agricultural abandonment and changing fire regimes. Modern vegetation patterns developed as the result of species-specific responses to the nature and timing of human activities, especially plowing, cutting, and fire. Although modern assemblages may be similar floristically to those that have occupied the site for centuries, presentday community structure and composition are largely the result of a specific cultural history. This is undoubtedly true of many natural areas valued for the uncommon communities and species that they currently support.

On Montague Plain, complex interactions of historical, physical, and biotic factors have contributed to the development of a remarkably heterogeneous landscape on a site that is edaphically homogeneous. Recognizing the spatial and temporal heterogeneity of vegetation and disturbance on Montague Plain, conservation efforts should perhaps be focused on retaining the integrity of this varied landscape rather than simply protecting portions of the landscape that currently support one or more uncommon species. Only through the long-term protection of functioning, dynamic landscapes will the complexity and heterogeneity of community patterns be ensured.

\section{CONCLUSIONS}

Montague Plain represents a point on the continuum of land-use impacts. Although $\approx 80 \%$ of the plain was plowed historically, our analyses suggest that this disturbance resulted in relatively minor long-term alteration of physical and chemical soil properties, presumably because of the short duration and light intensity of use of this agriculturally marginal site. However, even in the absence of long-term agricultural soil modification, the long-term impacts of land use on modern vegetation are striking as a result of species differences in colonization ability and responses to a complex history of disturbance processes. It is reasonable to conclude that on sites where the duration or intensity of agricultural use were greater and resulted in long-term alteration of site conditions, subsequent vegetation patterns would reflect the confounding effects of recolonization limitations and altered site conditions. Such an interaction is thought to be significant in many European systems (Peterken and Game 1981, 1984, Hermy 1994), and may well apply to broad areas of North America that have a long history of intensive agriculture.

\section{ACKNOWLEDGMENTS}

We thank R. A. Lent for significant contributions to data analyses. G. Rapalee carefully digitized all map overlays and M. Wallace gathered valuable historical data. W. A. Patterson III provided much valuable information and advice. R. Byard, 
J. Kaye, C. Whiting, and M. Wilkinson performed soil analyses. J. Bartos assisted with cation and soil moisture analyses conducted in the laboratory of P. L. M. Veneman. E. Ryan and K. Sherwood assisted with field sampling. E. Moriarity drafted several figures and D. Smith prepared the tables. J. Compton, S. Cooper-Ellis, K. Donohue, P. W. Dunwiddie, E. D. Ford, E. A. Johnson, J. McLachlan, J. F. O'Keefe, W. A. Patterson III, G. F. Peterken, P. Wilson, and an anonymous reviewer provided helpful comments on the manuscript. This work was supported by funds from A. W. Mellon Foundation, National Science Foundation (BSR-8811764, 9411764, DEB9408056), and R. T. Fisher Fund at Harvard University, and is a contribution of the Harvard Forest Long Term Ecological Research Program.

\section{Literature Cited}

Alban, D. H. 1979. Species influence on nutrients in vegetation and soils. Pages 152-171 in Proceedings Impact of Intensive Harvesting on Forest Nutrient Cycling. State University of New York, Syracuse, New York, USA.

Anonymous. 1974. Terrestrial ecology study of the Montague Plain site, Montague, MA. Pages 1-191 in Northeast Utilities, Montague Nuclear Power Station environmental report construction permit stage appendices. Volume 2. Industrial Bio-test Laboratories, Northbrook, Illinois, USA.

- 1982. MHC Reconnaissance Survey Report: Montague. Massachusetts Historical Commission, Boston, Massachusetts, USA.

Backman, A. E., and W. A. Patterson III. 1988. Vegetation and fire history of Myles Standish State Forest. Cooperative Forestry Research Unit Report Number 2, University of Massachusetts, Amherst, Massachusetts, USA.

. Binkley, D. 1986. Forest nutrition management. John Wiley and Sons, New York, New York, USA.

Birks, H. H., H. J. B. Birks, P. E. Kaland, and D. Moe, editors. 1988. The cultural landscape: past, present and future. Cambridge University Press, Cambridge, England.

Bockheim, J. G., S. W. Lee, and J. E. Leide. 1983. Distribution and cycling of elements in a Pinus resinosa plantation ecosystem, Wisconsin. Canadian Journal of Forest Research 13:609-619.

Bockheim, J. G., and E. A. Jepsen. 1991. Nutrient dynamics in decomposing leaf litter of four tree species on a sandy soil in northwestern Wisconsin. Canadian Journal of Forest Research 21:803-812.

Boerner, R. E. J. 1982. Fire and nutrient cycling in temperate ecosystems. BioScience 32:187-192.

Brady, N. C. 1990. The nature and properties of soils. Tenth edition. Macmillan, New York, New York, USA.

Bratton, S. P., and S. G. Miller. 1994. Historic field systems and the structure of maritime oak forest, Cumberland Island National Seashore, Georgia. Bulletin of the Torrey Botanical Club 121:1-12.

Brierly, W. B. 1938. The relation of Pinus rigida to physiographic features and soil types in central Massachusetts. Rhodora 40:72-73.

Britton, W. E. 1903. Vegetation of the North Haven sand plains. Bulletin of the Torrey Botanical Club 30:571-618.

Bromley, S. W. 1935. The original forest types of southern New England. Ecological Monographs 5:61-89.

Brunet, J. 1993. Environmental and historical factors limiting the distribution of rare forest grasses in south Sweden. Forest Ecology and Management 61:263-275.

Buell, M. F., and J. E. Cantlon. 1950. A study of two communities of the New Jersey Pine Barrens and a comparison of methods. Ecology 31:567-586.

Buell, M. F., and J. E. Cantlon. 1953. Effects of prescribed burning on ground cover in the New Jersey Pine Region. Ecology 34:520-528.

Chapin, F. S., III, and K. Van Cleve. 1978. Plant nutrient absorption and retention under differing fire regimes. Pages
301-321 in Proceedings Fire Regimes and Ecosystem Properties. U.S. Forest Service General Technical Report WO26.

Clapp, R. P. 1895. Settlement and early history of Montague. Pocumtuck Valley Memorial Association History and Proceedings 3(1890-1898):296-332.

Clark, R. L. 1982. Point count estimation of charcoal in pollen preparations and thin sections of sediments. Pollen et Spores 24:523-535.

Collins, F. S. 1909. Notes on the flora of lower Cape Cod. Rhodora 11:125-133.

Connell, J. H., and R. O. Slatyer. 1977. Mechanisms of succession in natural communities and their role in community stability and organization. American Naturalist 111:11191144.

Corson-Rickert, J. 1992. Roots Digitizing System. Decision Images, Skillman, New Jersey, USA.

Day, G. 1953. The Indian as an ecological factor in the northeastern forests. Ecology 34:329-346.

Duffy, D. C., and A. J. Meier. 1992. Do Appalachian herbaceous understories ever recover from clearcutting? Conservation Biology 6:196-201.

Dunwiddie, P. W. 1992. Changing landscapes. Nantucket Conservation Foundation, Nantucket Historical Association, Massachusetts Audubon Society, Reynolds DeWalt, New Bedford, Massachusetts, USA.

Dwight, T. 1821. Travels in New England and New York. T. Dwight, New Haven, Connecticut, USA.

Eastman, J. R. 1992. IDRISI Version 4.0. Clark University Graduate School of Geography, Worcester, Massachusetts, USA.

Egler, F. E. 1954. Vegetation science concepts: I. Initial floristic composition, a factor in old-field vegetation development. Vegetatio 4:412-417.

Fahey, T. J., and W. A. Reiners. 1981. Fire in the forests of Maine and New Hampshire. Bulletin of the Torrey Botanical Club 108:362-373.

Forman, R. T. T. 1979. Pine Barrens: ecosystem and landscape. Academic Press, New York, New York, USA.

Forman, R. T. T., and R. E. Boerner. 1981. Fire frequency and the Pine Barrens of New Jersey. Bulletin of the Torrey Botanical Club 108:34-50.

Foster, D. R. 1992. Land-use history (1730-1990) and vegetation dynamics in central New England, USA. Journal of Ecology 80:753-772.

Givnish, T. J., E. S. Menges, and D. F. Schweitzer. 1988. Minimum area requirements for long-term conservation of the Albany Pine Bush and Karner Blue Butterfly: an assessment. Malcolm Pirnie, Albany, New York, USA.

Glitzenstein, J. S., C. D. Canham, M. J. McDonnell, and D. R. Streng. 1990. Effects of environment and land-use history on upland forests of the Cary Arboretum, Hudson Valley, New York. Bulletin of the Torrey Botanical Club 117:106-122.

Gomez-Pompa, A., and A. Kaus. 1992. Taming the wilderness myth. BioScience 42:271-279.

Harshberger, J. W. 1916. The vegetation of the New Jersey Pine Barrens. Christopher Sower, Philadelphia, Pennsylvania, USA.

Hawes, A. F. 1923. New England forests in retrospect. Journal of Forestry 21:209-224.

Hermy, M. P. 1994. Effects of former land use on plant species diversity and pattern in European deciduous woodlands. Pages 123-144 in T. J. B. Boyle and C. E. B. Boyle, editors. Biodiversity, temperate ecosystems, and global change. Springer-Verlag, Berlin, Germany.

Hermy, M. P., P. van den Bremt, and G. Tack. 1993. Effects of site history on woodland vegetation. Pages 219-232 in M. E. A. Broekmeyer, W. Vos, and H. Koop, editors. Eu- 
ropean forest reserves. Pudoc Scientific, Wageningen, The Netherlands.

Hill, M. O. 1979a. DECORANA-a FORTRAN program for detrended correspondence analysis and reciprocal averaging. Cornell University, Ithaca, New York, USA.

1979b. TWINSPAN-a FORTRAN program for arranging multivariate data in an ordered two-way table by classification of the individuals and attributes. Cornell University, Ithaca, New York, USA.

Hillel, D. 1982. Introduction to soil physics. Academic Press, San Diego, California, USA.

Howe, C. D. 1910. The reforestation of sand plains in Vermont. Botanical Gazette 49:126-148.

Hunter, M. L., Jr., G. L. Jacobson Jr., and T. Webb III. 1988. Paleoecology and the coarse-filter approach to maintaining biological diversity. Conservation Biology 2:375-385.

Huston, M., and T. Smith. 1987. Plant succession: life history and competition. American Naturalist 130:168-198.

Inouye, R. S., N. J. Huntly, D. Tilman, J. R. Tester, M. Stillwell, and K. C. Zinnel. 1987. Old-field succession on a Minnesota sand plain. Ecology 68:12-26.

Jahns, R. H. 1966. Surficial geologic map of the Greenfield Quadrangle, Franklin County, Massachusetts. U.S. Geological Survey Map GQ-474.

Judd, S. 1905. History of Hadley including the early history of Hatfield, South Hadley, Amherst and Granby. Second edition. H. R. Huntting, Springfield, Massachusetts, USA

Little, S. 1964. Fire ecology and forest management in the New Jersey Pine Region. Proceedings of the Tall Timbers Fire Ecology Conference 3:34-59.

1979. Fire and plant succession in the New Jersey Pine Barrens. Pages 297-314 in R. T. T. Forman, editor Pine Barrens: ecosystem and landscape. Academic Press, New York, New York, USA.

Little, S., and P. W. Garrett. 1990. Pinus rigida Mill. Pages 456-462 in R. M. Burns and B. H. Honkala, technical coordinators. Silvics of North America. Volume 1, Conifers. United States Department of Agriculture Handbook 654.

Little, S., and E. B. Moore. 1949. The ecological role of prescribed burns in the pine-oak forests of southern New Jersey. Ecology 30:223-233.

Lutz, H. J. 1934. Ecological relations in the pitch pine plains of southern New Jersey. Yale University School of Forestry Bulletin Number 38, New Haven, Connecticut, USA.

Massachusetts Archives. 1830. Map of the Town of Montague. Boston, Massachusetts, USA.

Matlack, G. R. 1994. Plant species migration in a mixedhistory forest landscape in eastern North America. Ecology 75:1491-1502.

Matlack, G. R., D. J. Gibson, and R. E. Good. 1993. Regeneration of the shrub Gaylussacia baccata and associated species after low-intensity fire in an Atlantic Coastal Plain forest. American Journal of Botany 80:119-126.

Matlack, G. R., and R. E. Good. 1990. Spatial heterogeneity in the soil seed bank of a mature Coastal Plain forest. Bulletin of the Torrey Botanical Club 117:143-152.

McCune, B. 1993. Multivariate analysis on the PC-ORD System. Oregon State University, Corvallis, Oregon.

Miller, H. G., J. M. Cooper, J. D. Miller, and O. J. L. Pauline. 1979. Nutrient cycles in pine and their adaptation to poor soils. Canadian Journal of Forest Research 9:19-26.

Milne, B. T. 1981. Vegetational gradients and succession in the tree and shrub strata of the Albany Pine Bush, Albany, New York. Thesis. State University of New York, Albany, New York, USA.

- 1985. Upland vegetational gradients and post-fire succession in the Albany Pine Bush, New York. Bulletin of the Torrey Botanical Club 112:21-34.

Mott, J. R., and D. C. Fuller. 1967. Soil survey of Franklin
County, Massachusetts. U.S. Dept. of Agriculture, Soil Conservation Service, Washington, D.C., USA.

Niering, W. A. 1953. The past and present vegetation of High Point State Park, New Jersey. Ecological Monographs 23: 127-148.

Niering, W. A., and G. D. Dreyer. 1989. Effects of prescribed burning on Andropogon scoparius in postagricultural grasslands in Connecticut. American Midland Naturalist 122 88-102.

Olmsted, C. E. 1937. Vegetation of certain sand plains of Connecticut. Botanical Gazette 99:209-300.

Olsvig, L. S. 1980. A comparative study of Northeastern pine barrens vegetation. Dissertation. Cornell University, Ithaca, New York, USA.

Patterson, W. A., III, and K. E. Sassaman. 1988. Indian fires in the prehistory of New England. Pages 107-135 in G. P. Nicholas, editor. Holocene human ecology in northeastern North America. Plenum, New York, New York, USA:

Patterson, W. A., III, K. E. Saunders, and L. J. Horton. 1984. Fire regimes of Cape Cod National Seashore. United States Department of the Interior, National Park Service Office of Scientific Programs, Report OSS 83-1, Boston, Massachusetts, USA

Peterken, G. F., and M. Game. 1981. Historical factors affecting the distribution of Mercurialis perennis in central Lincolnshire. Journal of Ecology 69:781-796.

Peterken, G. F., and M. Game. 1984. Historical factors affecting the number and distribution of vascular plant species in the woodlands of central Lincolnshire. Journal of Ecology 72:155-182.

Pressey, E. P. 1910. History of Montague: a typical Puritan town. Montague, Massachusetts, USA.

Prévost, M., and H. A. Bolghari. 1990. Growth and rooting of two black spruce provenances in relation to soil bulk density and soil moisture. Canadian Journal of Forest Research 20:185-192.

Pritchett, W. L. 1979. Soil as a reservoir: soil nutrient supplies and mobilization rates. Pages 49-61 in Proceedings Impact of Intensive Harvesting on Forest Nutrient Cycling. State University of New York, Syracuse, New York, USA.

Rapp, M. 1983. Some problems of disturbance on the nutrient cycling in ecosystems. Pages 118-128 in H. A. Mooney and M. Godron, editors. Disturbance and ecosystems. Springer-Verlag, New York, New York, USA.

Reiners, W. A. 1965. Ecology of a heath-shrub synusia in the pine barrens of Long Island, New York. Bulletin of the Torrey Botanical Club 92:448-464.

1967. Relationships between vegetational strata in the pine barrens of central Long Island, New York. Bulletin of the Torrey Botanical Club 94:87-99.

Rice, W. R. 1989. Analyzing tables of statistical tests. Evolution 43:223-225.

Ricklefs, R. E. 1987. Community diversity: relative roles of local and regional processes. Science 235:167-171.

Ruark, G. A., and J. G. Bockheim. 1988. Biomass, net primary production, and nutrient distribution for an age sequence of Populus tremuloides ecosystems. Canadian Journal of Forest Research 18:435-443.

Schweitzer, D. F., and T. J. Rawinski. 1988. Northeastern pitch pine/scrub oak barrens. Eastern Heritage Task Force, The Nature Conservancy, Boston, Massachusetts, USA.

Seischab, F. K., and J. M. Bernard. 1991. Pitch pine (Pinus rigida Mill.) communities in central and western New York. Bulletin of the Torrey Botanical Club 118:412-423.

Seymour, F. C. 1989. The flora of New England. Second edition. Phytologia Memoirs V. Plainfield, New Jersey, USA.

Specht, R. L. 1979. Heathlands and related shrublands of the world. Pages 1-18 in R. L. Specht, editor. Ecosystems 
of the world 9A: heathlands and related shrublands. Elsevier, Amsterdam, The Netherlands.

Thihatmer, J. 1989. Influence of soil density and humus content on the growth of Scots pine and Douglas fir on sandy soils in forest nurseries. Über die Einflüsse der Bodendichte und des Humusgehalts auf die Wuchsleistungen von Kiefern und Douglasien sandiger Böden in Forstbaumschulen. Beiträge für die Forstwirtschaft 23:25-29.

Thomas, G. W. 1982. Exchangeable cations. Pages 159-164 in A. L. Page, R. H. Miller, and D. R. Keeney, editors. Methods of soil analysis, part 2. Chemical and microbiological properties. Second edition. American Society of Agronomy, Soil Science Society of America, Madison, Wisconsin, USA.

Thomas, P. A. 1974. Archaeological and historical impact statement, Northeast Utilities Corporation Montague Nuclear Power Station, Montague, Franklin County, Massachusetts. Massachusetts Historical Commission, Boston, Massachusetts, USA.

- 1975. Phase II: Archaeological and historical impact statement, Northeast Utilities Corporation Montague Nuclear Power Station, Montague, Franklin County, Massachusetts. Massachusetts Historical Commission, Boston, Massachusetts, USA.

Tilman, D. 1987. Secondary succession and the pattern of plant dominance along experimental nitrogen gradients. Ecological Monographs 57:189-214.

Torrey, B., and F. H. Allen, editors. 1962. The journal of Henry D. Thoreau. Volume 1. Dover, New York, New York, USA.

Troeh, F. R., and L. M. Thompson. 1993. Soils and soil fertility. Fifth edition. Oxford University Press, Oxford, England.

Turner, B. L., II, W. C. Clark, R. W. Kates, J. F. Richards, J. T. Mathews, and W. B. Meyer, editors. 1990. The earth as transformed by human action. Cambridge University Press, Cambridge, England.
United States Department of Agriculture. 1993. Soil Survey Manual. USDA Handbook Number 18.

Veneman, P. L. M. 1985. Laboratory data and descriptions for selected soils in Massachusetts I. Research Bulletin Number 706. Massachusetts Agricultural Experimental Station, University of Massachusetts at Amherst, Massachusetts, USA.

Wacker, P. O. 1979. Human exploitation of the Pine Barrens before 1900. Pages 1-24 in R. T. T. Forman, editor. Pine Barrens: ecosystem and landscape. Academic Press, New York, New York, USA.

Wells, T. C. E., J. Sheail, D. F. Ball, and L. K. Ward. 1976. Ecological studies on the Porton Ranges: relationships between vegetation, soils and land-use history. Journal of Ecology 64:589-626.

Whitney, G. G. 1994. From coastal wilderness to fruited plain. Cambridge University Press, Cambridge, England.

Whitney, G. G., and D. R. Foster. 1988. Overstorey composition and age as determinants of the understorey flora of woods of central New England. Journal of Ecology 76: 867-876.

Whittaker, R. H. 1979. Vegetational relationships of the Pine Barrens. Pages 315-331 in R. T. T. Forman, editor. Pine Barrens: ecosystem and landscape. Academic Press, New York, New York, USA.

Whittaker, R. H., and G. M. Woodwell. 1968. Dimension and production relations of trees and shrubs in the Brookhaven Forest, New York. Journal of Ecology 56:1-25.

Widoff, L. 1987. Pitch pine-scrub oak barrens in Maine. Critical Areas Planning Program Report Number 86. Maine State Planning Office, Augusta, Maine, USA.

WPA. 1937. Land-use map for Town of Montague. Project Number 13684. Massachusetts State Planning Board, Works Progress Administration, Boston, Massachusetts, USA. 